\title{
GOVERNANCE QUALITY AND TAX REVENUE MOBILIZATION IN NIGERIA
}

\author{
Peace Ngozi Johnson \\ Department of Accounting, College of Management and Social Sciences, Covenant University Ota, \\ Ogun State, Nigeria, E-mail: peace.johnson@stu.cu.edu.ngcom
}

\section{Cordelia Onyinyechi Omodero*}

Department of Accounting, College of Management and Social Sciences, Covenant University Ota, Ogun State, Nigeria, E-mail: onyinyechi.omodero@covenantuniversity.edu.ng

(Received: September 2021; Accepted: November 2021; Published: December 2021)

\begin{abstract}
An evaluation of the quality of governance as a major determinant of tax revenue generation is important to both the government and the Nigerian public. It has become required as a result of many rising economies' reliance on several taxes to raise income. Tax income generation is crucial to the fulfillment of the Sustainable Development Goals (SDGs) and rising economies' economic progress. This study addresses the influence of both political (political stability), institutional (corruption) and bad governance on the mobilization of tax revenue in Nigeria. To serve this purpose, the study employed a time series data set from 2000 to 2020. After subjecting the data to the unit root test, the study further employs Ordinary Least Square (OLS). The findings revealed that corruption and political instability have a positive and significant impact on Nigeria's tax revenue mobilization. Bad governance, on the other hand, has a positive and insignificant influence on Nigeria's tax revenue mobilization. The study focuses on improving governance quality by lowering corruption rates and increasing transparency in tax administration. To accomplish so, countries must execute policy reforms such as establishing an effective and strict judicial system, offering monetary incentives for tax officers to lower the risk of corruption, and, most crucially, broadening the revenue base rather than raising tax rates. As a result, the tax administration will improve, and the economy's overall tax revenue collection will improve.
\end{abstract}

Keywords: governance quality; political instability; corruption; tax revenue mobilization.

\section{Introduction}

Tax revenue is the set amount of money that citizens of a country lawfully pay to the government in order to support the country's economic and social development in

$\begin{array}{lllll}\text { Corresponding author: Cordelia } & \text { Onyinyechi } & \text { Omodero. } & \text { E-mail: } \\ \text { onyinyechi.omodero@covenantuniversity.edu.ng }\end{array}$

Copyright (C) 2021 The Author(s). Published by VGWU Press

This is an Open Access article distributed under the terms of the Creative Commons BY 4.0 license (Creative Commons - Attribution 4.0 International - CC BY 4.0) which permits unrestricted use, distribution, and reproduction in any medium, provided the original author and source are credited. 
Johnson, P.N., Omodero, C.O., (2021)

Governance Quality and Tax Revenue Mobilization in Nigeria

enforceable ways (Michael, 2015). Despite the fact that taxation is an important tool for fiscal policy in mobilizing resources and promoting capital formation in the public sector, there is a significant mismatch between the ever-increasing demand for government expenditure and the limited scope of tax revenue raised to finance such development scenarios, indicating that low-income countries face a tax revenue challenge (Saibu \& Olasunbo, 2013; Joyce, 2014). As a result, tax income collection in less developed countries has become a major challenge, attracting a lot of attention. It is critical to increase tax income to reduce undue reliance on foreign aid, manage macroeconomic challenges, restrict borrowing, and promote vigorous economic growth. In emerging countries, raising the tax-to-GDP ratio is an explicit policy goal (Zulal, 2005; Saibu \& Olasunbo, 2013).

Revenue generation, redistribution of money, restriction of social evils through repricing of particular goods and services such as tobacco and alcohol, and representation, which is the area of democratic state-building and the very need for revenues, all began with taxation in the twentieth century (Owens, 2015). The link between taxation and government services, in general, is created through the evolution of taxation over time. There will be no upheaval as long as government services to taxpayers are commensurate with the level of taxes (Ross, 2004). The state is focusing on upgrading its tax system to generate more tax income in a robust economy reliant on taxation (Gupta, 2007). Taxation is a vital component in the growth of middle- and low-income countries (Russell, 2010). A country's ability to increase its tax base, both economically and administratively, is crucial to its income generation. Because of the shortcomings of tax administrators, there is a gap between what is collected and what is intended to be obtained by law, indicating the need for tax administration reform (Kebede \& Tegegn, 2016). The tax revenue collected by developing countries appears to be insufficient due to institutional issues such as corruption, political instability, and ineffective tax administration, policies, and legislation. Reforms to the tax administration and system are considered important for increasing the amount of tax income generated in emerging countries while maintaining political stability (Ajaz \& Ahmad, 2010). As a result, institutional quality is the fundamental predictor of tax collection in developing and developed countries, as institution problems are viewed as the primary cause of abysmal tax collection in poorer countries (Ghura, 1998). Several tax reforms have been implemented in the country to increase tax collection. However, they have had little impact. In Nigeria, the hunt for a long-term source of public funding has placed taxation at the forefront of public debate and attention. This is exacerbated by falling oil revenues, which has led to a greater reliance on debt to fund the country's annual budget. Borrowing to shore up revenue, according to the International Monetary Fund, is not sustainable. The Minister of Finance has backed this up with repeated recommendations to increase domestic resource mobilization, emphasizing revenue. 
Johnson, P.N., Omodero, C.O., (2021)

Governance Quality and Tax Revenue Mobilization in Nigeria

Tax income and non-tax revenue are two types of financial resources that the government uses to fulfill its various tasks. According to Alabede (2001) and Olaofe (2008), taxation is the primary source of revenue for some governments. However, Eshag (1983) claimed that the quantity of tax money collected by the government for its spending program is determined, among other things, by the taxpayers' willingness to follow the country's tax regulations. It is widely acknowledged that some people dislike paying taxes, and as a result, tax officials find it difficult to levy and collect taxes at any location and at any time (Alm, Martinez- Vazquez \& Schneider, 2004). Failure to comply with tax provisions may indicate that a taxpayer is engaged in noncompliance (Kirchler, 2007). According to Franzoni (2000), tax disobedience is the most widespread and serious of all tax administration issues. Tax evasion is a global problem that affects both poor and rich countries (McGee, 2006). As a result of the presence of a substantial informal economy, which is the hard-totax sector, tax revenue losses in developing nations are disproportionately bigger than in industrialized countries (Terkper, 2003). In 2002, the average tax income loss in developing countries was estimated to be between 35 percent and 55 percent of GDP, according to available data (Terkper, 2003). These projections climbed by 14 percent to 27 percent from 1993 forecasts of 30 percent to 40 percent of GDP, respectively (Feige, 1989 \& Plyle, 1998). According to Cobham (2005), developing countries lose US\$285 billion in tax income each year owing to noncompliance.

Public governance quality is necessary to have a good tax system and equally good tax system to achieve public governance quality (Everest-Philip \& Sandall, 2009). Citizens assist the government in fulfilling its tasks by providing financial assistance in the form of tax payments. The taxpayers should be concerned about what is going on in the government since they are the ones who fund it. As a result, governance issues may have either a beneficial or negative impact on taxpayer compliance behavior (Alabede, Ariffin \& Idris, 2011). When Levi (1988) looked into the interaction between taxpayers and the government, he found that vertical contract impacts tax compliance. He describes the relationship between taxpayers and the government as a vertical contract or quid pro quo of taxes. The vertical contract examines whether taxpayers receive public goods in exchange for their taxes. According to the quid pro quo theory, compliance with tax law provisions is contingent in part on whether the government's political goods are sufficient in exchange for the taxes they pay (Lassen, 2003). Levi (1988) claimed that if taxpayers believe the rate of transformation from tax to political goods is low, they would believe the government has failed to fulfill its contractual obligations, and voluntary tax compliance will suffer as a result. Besancon (2003) agreed with Levi (1988) that there is a social compact between the government (ruler) and the taxpayers (ruled) that embodies the effective delivery of political goods. In addition, Lassen (2003) stated that the political goods mix supplied by the government is also important and 
Johnson, P.N., Omodero, C.O., (2021)

Governance Quality and Tax Revenue Mobilization in Nigeria

that if the political goods mix supplied by the government is very different from those they prefer, or if the rate of transformation is low due to corruption, taxpayers may feel the attractiveness of the quid pro quo contract is diminished, and that this could lead to litigation.

There are signs in Nigeria that the quality of public governance is not up to par. According to Natufe (2006), Nigeria is experiencing a fundamental crisis in public governance. The condition of decay in Nigeria's public infrastructure and economic activities manifests inadequate public governance (Abati, 2006). Religious and interethnic strife and deterioration in infrastructures such as education, power, health, and roads are all indices and symptoms of Nigeria's weak public governance (Natufe, 2006). Madueke (2008) found widespread dissatisfaction with the quality of Nigerian public governance, blaming the problem on a lack of corruption control, a lack of the rule of law, and poorly stated government policies. Lewis (2006) and Lewis and Alemika (2005) investigations found decreased public satisfaction with government performance and democratic dividends in Nigeria. Fagbadebo (2007) also stated that Nigeria is a victim of bad public governance and that to promote effective public governance in Nigeria, Accountability and transparency must be assured. We claim that the perception of public governance quality in Nigeria affects taxpayer compliance behavior, based on the foregoing empirical findings and the social exchange theory.

\subsection{Statement of Research Problem}

The poor level of tax compliance in Nigeria is revealed by assessing the country's tax revenue position and other pertinent indicators. According to the Federal Inland Revenue Service, the country's overall tax collection in 2019 was 5.26 trillion naira ( $\$ 13.5$ billion). Assuming that this number represents income tax collected from Nigeria's 3.1 million registered firms (Corporate Affairs Commission, March 2019), the average tax payment per business will be 1,710 naira (less than \$5). In light of publicly-traded firms' tax payments and remittances from the oil and gas sector, and in a country where corporations pay a minimum tax regardless of their profitability, this is a dismal figure.

Furthermore, the data on tax payments by economically engaged citizens are equally alarming. Nigeria's employed population was estimated to be 69.5 million individuals in September 2018 by the Nigerian Bureau of Statistics (NBS). However, the individual tax-paying population is projected to be 19 million, implying that around 50.5 million Nigerians are employed but not paying taxes (NBS). In 2018, the 36 federal states and the Federal Capital Territory (FCT) collected 669 billion naira in total tax income, resulting in an average of 35,211 naira per registered taxpayer and a pitiful 6,021 naira per economically active individual. As a result of the foregoing, the country's tax revenue profile reflects the state of the fiscal contract 
Johnson, P.N., Omodero, C.O., (2021)

Governance Quality and Tax Revenue Mobilization in Nigeria

between its residents and the government. Nigeria's tax revenue problem can be traced back to a shattered social compact that has bred a culture of tax fraud among citizens. To put it another way, tax morale is low, which has resulted in tax evasion, involuntary tax compliance, tax fraud, apathy toward tax concerns, and other concerns impeding the government's efforts to increase tax income.

It is important to identify factors that shape or affect tax morale as it affects tax revenue mobilization. Tax morale has many features which are influenced by a variety of aspects. Various studies identified various factors that affect tax morale. One of the factors is governance quality (Hossain, 2014). Poor governance quality generally undermines the tax morale of the citizens because they get frustrated. Furthermore, there might be a crowding-out effect of morality among the tax administrators when there are many corrupt colleagues. Taxpayers will feel cheated if they believe that this corruption is widespread and their tax burden is not spent well. Corrupt bureaucracy will not award the services to the most efficient producers, but to the producer who offers the larger bribes. Thus, corruption reduces allocation efficiency and produces delays in transactions to acquire additional payments (Schlenther, 2017; Mauro, Medas \& Fournier, 2019). This study is to determine the level of influence of political (political instability), institutional (corruption) and bad governance on tax compliance.

Several studies have identified a number of problems as impeding long-term tax revenue collection, including the view that taxes do not result in the provision of services. Authors like (Epaphra \& Massawe, 2017; Arif \& Rawat, 2018; Bird, Martinez-Vazquez \& Torgler, 2014; Saibu \& Olatunbosun, 2013; Lien, 2015; Akintoye, Adegbie \& Awotomilusi, 2019), revealed in their studies various variables of public governance quality as major determinants of tax effort in various developing countries. However, scanty literature has been reviewed on the impact of public governance quality on tax revenue mobilization in Nigeria. Besides no literature amidst the few already written considered both political, institutional and bad governance as proxies for governance quality in Nigeria. That is, it was either one or the other.

Moreso, Authors like (Terefe \& Teera, 2018; Abhijit, 2007; Urhoghide \& Asemota, 2013; Mohamed \& Robert, 2014), confirmed per capita GDP, foreign aid, trade openness and other structural factors to be major determinants of tax revenue generation across various African countries. Nevertheless, these studies emphasized only the supply determinants of tax revenue. This study aims to fill this research gap.

\subsection{Objectives of the Study}

The study's broad objective is to access how the Nigerian tax revenue mobilization responds to governance quality. However, specific objectives are to:

i. examine the casualty between corruption and tax revenue in Nigeria; 
Johnson, P.N., Omodero, C.O., (2021)

Governance Quality and Tax Revenue Mobilization in Nigeria

ii. determine the relationship between political instability and tax revenue in Nigeria;

iii. analyze bad governance effect on tax revenue in Nigeria.

\subsection{Research Questions}

The research questions below are addressed in this study:

i. Is there a relationship between corruption and tax revenue in Nigeria?

ii. What is the relationship between political instability and tax revenue in Nigeria?

iii. Does the bad governance in Nigeria affect the tax revenue generation?

\subsection{Statement of the Hypotheses}

In line with the research problems and objectives, the following hypotheses were formulated and tested.

$\mathrm{H}_{0} 1$ : There is no significant relationship between corruption and tax revenue in Nigeria.

$\mathrm{H}_{0}$ 2: There is no significant relationship between political instability and tax revenue in Nigeria.

$\mathrm{H}_{0} 3$ : The bad governance in Nigeria has no significant effect on tax revenue generation in Nigeria.

\section{Literature review}

\subsection{Conceptual Framework}

The conceptual framework examines the many concepts of governance quality as an independent variable and tax revenue mobilization as a dependent variable in great depth. This framework also explains the notion, which improves the comparability of the variables in this study. A conceptual framework represents the researcher's synthesis of the literature on explaining a phenomenon. Given his prior knowledge of other researchers' points of view and observations on the area of research, it lays out the actions that must be taken during the investigation. In other words, the conceptual framework is the researcher's understanding of how the variables in his study connect (Regoniel, 2015).

\subsubsection{Concept of Taxation}

Taxation is viewed as a burden that every person must bear for their government to continue to exist because the government has specific obligations to complete for the benefit of the people it governs. Taxation is one of the government's sources of revenue, according to Farayola (2007), and it is used to finance or operate public facilities and fulfill other social responsibilities. A tax is a levy levied by the government on an individual's or a corporation's income, profit, or wealth, according 
Johnson, P.N., Omodero, C.O., (2021)

Governance Quality and Tax Revenue Mobilization in Nigeria

to Ochiogu (2014). Taxation is the most important source of revenue for modern governments, according to Adams (2011), accounting for 90 percent or more of their revenue. Aguolu (2014) defines taxes as a mandatory fee imposed by the government on its subjects' income, consumption, and capital through its agencies. Salary, firm earnings, interest, dividends, discounts, and royalties are all subject to taxation. It also covers a company's petroleum revenue, capital gains, and capital transfers.

On the other hand, Ojo (2008) underlines that taxation is both a concept and science that entails imposing a tax on citizens. Taxation, he claims, is a legal obligation that every person must fulfill. It is frequently seen as a civic duty. According to Okon (2007), income tax is a fiscal policy tool used by governments all over the world to influence the good or negative outcomes of specific sorts of economic activities to achieve desired outcomes.

The substantial reduction in oil price in recent years has resulted in a decrease in the cash available for distribution to the different tiers of government and execution of capital projects for development reasons (Jimoh\&Adegoriola, 2020). The researchers betoned that the requirement for the government to produce appropriate internal sources of revenue has become a matter of urgency and importance. This requirement highlights the propensity of state, municipal, and even federal governments to seek new sources of money or to become more aggressive and imaginative in collecting tax from existing ones. Knowing the importance of taxation in achieving its expenditure requirements, the Nigerian government embarked on various tax reforms. However, because most of the reforms concentrated on tax structure rather than tax administration, the latter aimed to produce greater income from current tax sources. These reforms failed to fulfill their intended goals (Oriakhi \& Ahuru, 2014).

The recent crash in the international oil market (loss in oil revenue) and the subsequent economic slump in Nigeria highlight the necessity of competent tax management for better non-oil revenue. The recent drop in oil revenues has turned the Nigerian government's attention to finding alternative sources of cash to fund its numerous projects. According to public finance professionals, economists, and other stakeholders, taxation is a viable tool for this aim. Deng (2015), for example, stated that taxation, as a macrocosmic policy tool, impacts the level and rate of economic growth in countries around the world. This meant that a country's tax system (i.e., how taxes are assessed and collected) might significantly impact other macroeconomic indicators, for both developed and developing countries, specifically.

The usefulness of taxation as a flexible instrument for economic growth and development is mostly dependent on a well-designed tax system that can generate money. Because taxation is an important source of revenue for governments, the extent to which the Nigerian tax system provides the necessary revenue to fulfill the 
Johnson, P.N., Omodero, C.O., (2021)

Governance Quality and Tax Revenue Mobilization in Nigeria

government's ever-increasing expenditure burden is cause for concern. As a result, the tax system needs to be productive. The ability of a tax system to generate maximum money for the government with a given tax base while imposing a difficult economic burden on the taxpayer is referred to as its productivity (Jimoh \& Adegoriola, 2020).

The low productivity of the Nigerian tax system has been a source of worry for successive governments. This has generally been attributed to flaws in the tax administration and collecting system, confusing legislation, and apathy, particularly among those outside the tax net (Ariyo \& Bekoe, 2012; Ogbuabor, Aneke \& Ogbuabor, 2014). A system based on the ability to pay is supposed to be progressive in a situation where the tax administration is ineffectual, but it is usually regressive, especially when there is a lack of tax compliance. If a tax system is efficient and effective, revenue generated as a percentage of national income should be close to or greater than $100 \%$ of the tax's standard rate (Ngerebo \& Masa, 2012). For example, suppose the effectiveness of the personal income tax system is to be assessed. In that case, the tax revenue generated by the personal income tax rate on national income should be divided by the current average personal income tax rate (Ebrill, Bodin \& Summers, 2001). Because tax is deducted from total income, the amount of tax generated should be equal to the tax rate multiplied by national income. When the proportion is lower than the standard rate, the tax system is not productive and thus ineffective. Suppose the proportion is less than the normal tax rate, which is calculated by dividing the revenue collected by the total consumption expenditure. In that case, the tax system is said to be unproductive and inefficient because it has not affected consumption as it was intended.

Due to a lack of strong administration, Nigeria has been one of the most behind developing countries in revenue collection. In recent years, the most concerning aspect of Nigeria's economy has been weak governance, corruption, and mismanagement, which has hindered the country's resources from taxation and other sources from being channeled towards long-term development in a self-sustaining economy (Jimoh \& Adegoriola, 2020). Despite increased revenue creation that was ostensibly invested in productive initiatives, the economy nonetheless has a high unemployment rate of 23.1 percent and a high inflation rate of 11.28 percent (NBS, 2018). It is also worth noting that between 2005 and 2015, total oil revenue accounted for 82.36 percent of overall revenue, while non-oil revenue accounted for only 17.64 percent (CBN Statistical Bulletin, 2016). Even in the midst of multiple adjustments and implementations of various tax revenue regulations, this is a strong sign that our generation potential is totally dependent on oil money. This indicates a significant level of inefficiency in Nigeria's tax administration, which runs counter to Friedman's (1978) tax-and-spend hypothesis, which holds that changes in

\footnotetext{
8 Journal of Legal Studies Volume 28 Issue 42/2021

$\checkmark$ sciendo ISSN 2457-9017; Online ISSN 2392-7054.

Web: publicatii.uvvg.ro/index.php/jls. Pages $1-41$
} 
Johnson, P.N., Omodero, C.O., (2021)

Governance Quality and Tax Revenue Mobilization in Nigeria

government revenue lead to changes in government expenditure with the sole purpose of promoting economic growth.

According to Anao (1988), the Nigerian government has failed to meet expectations in terms of earning adequate revenue to offer social and essential services to its citizens. This is because the government's internal income production machinery is not adequately coordinated to the point where it can efficiently achieve the goals for which it was created. Furthermore, according to Naiyeju (1996), the success or failure of any tax system is determined by how well it is administered and how well the tax law is read and applied. Dickson and Presley (2013) also blame this deficiency on a high percentage of tax evasion, erroneous tax exemptions, and tax administration corruption.

\subsubsection{Tax Revenue Mobilisation}

Tax revenue mobilization is a significant priority for policymakers in many countries. While some countries have witnessed considerable increases in their taxto-GDP ratios throughout time, others have seen little or no change. Increased domestic resource mobilization is critical for many countries. Enhancing tax revenue collection is crucial for governments to give fiscal flexibility to fund public investments and deliver public services, particularly in developing nations.

According to Drummond, Daal, Srivastava, \& Oliveira (2012), collecting additional revenue is a priority for Sub-Saharan African (SSA) governments due to the limited resources available for implementing the huge infrastructure required in most SSA countries. These countries have massive development agendas to implement, and insufficient income mobilization is the main cause of fiscal imbalances in numerous of the region's countries.

Several academics have conducted research on income mobilization in poor nations, particularly in Sub-Saharan Africa (SSA). In addition to usual measurements, these researchers looked at the role of institutional characteristics such as institutional quality and governance in influencing these countries' ability to raise income. These factors are thought to have an impact on the tax revenue by contributing to high levels of tax evasion, inappropriate tax exemptions, and ineffective tax administration (Tanzi \& Davoodi, 1998). This is a factor in the Nigerian instance, where some political godfathers and elite may pull strings to get exemptions for corporations in which they have a stake. This is also why some of these heavyweights are frequently found on the boards of directors of some of the corporations.

Bird, Martinez-Vasquez, \& Torgler (2004) find empirical evidence that variables including corruption, the rule of law, and entry regulations are important. Where certain revenue collectors collude with taxpayers to collect less than what the individual or firm is owed in exchange for "settlement."Any successful tax reform aimed at overcoming these hurdles, according to Bird (2004), must be backed by a 
Johnson, P.N., Omodero, C.O., (2021)

Governance Quality and Tax Revenue Mobilization in Nigeria

strong political commitment to reform, which includes establishing institutions strong enough to avoid being criticized by some political and economic heavyweights in society. Furthermore, Bird, Martinez-Vazquez, \& Torgler (2004) argue that in order to achieve efficient revenue mobilization through proper tax collection, a political leadership capable of ensuring respect to the rule of law and effective corruption control inside its territory is required.

\subsubsection{Problems of Revenue Mobilisation in Nigeria}

Bahl \& Smoke (2003), state that one major administrative problem experienced by several countries in Africa is their inability to collect fully the revenue due to them as there are huge gaps between the actual and the projected revenues. According to Adedokun, (2007), Atakpa, Ocheni, Nwankwo (2012); and Agya et al. (2015), the following are major factors responsible for the low and poor revenue mobilization in Nigeria:

i. Shortage of well trained and qualified personnel which suppose to serve as a tool for the collection of taxes and rates, even the few available are not properly groomed in efficient budgetary and financial management system.

ii. Lack of commitment on the part of the revenue collector, based on the fact that most of the revenue collectors are totally dishonest.

iii. Defects in revenue collecting machinery.

iv. Familiarity between the revenue collectors and the people of the council areas.

\subsubsection{Governance Quality and Tax Revenue Mobilisation}

Citizens of countries are interested in governance quality because it is linked to the benefits they receive from the government. The World Bank (2006) defines public governance quality as the process of selecting, evaluating, and replacing a country's leadership, as well as the government's ability to effectively and efficiently handle the country's resources in a fair and equitable manner. In addition, good governance emphasizes policy soundness, delivery of public goods and services, and citizen respect and participation in decision-making. As a result, the link between public governance quality and tax revenue mobilization is based on the implied social contract, which states that citizens who provide financial support to government and its functions by paying their fair share of taxes have a right to know what happens to those taxes, how they are spent, and what tangible benefits they receive (Dickerson, 2014; Vlachos \& Bitzenis, 2018). According to Alabede \& Affrin (2011), if taxpayers believe that the rate and scale at which taxes are converted to political goods is small, they would believe that the government is failing to fulfill its own share of the social compact, and so voluntary compliance will decline. Although a

\footnotetext{
10 Journal of Legal Studies Volume 28 Issue 42/2021

$\checkmark$ sciendo ISSN 2457-9017; Online ISSN 2392-7054.

Web: publicatii.uvvg.ro/index.php/jls. Pages $1-41$
} 
Johnson, P.N., Omodero, C.O., (2021)

Governance Quality and Tax Revenue Mobilization in Nigeria

variety of factors influence tax revenue collection, the importance of governance quality cannot be overstated.

According to Torgler (2005), inadequate governance may limit the degree of tax revenue mobilization, and tax compliance will suffer as a result. Furthermore, shedding more light on the governance and tax compliance linkage, Torgler (2005) posit that when people are satisfied with the level and quality of political goods financed from their tax investment, their tax compliance levels may escalate. Analyzing this relationship deeply, Everest-Phillips and Sandall (2009) advance that there is an interdependent connection between governance quality and taxation and that governance quality influences the design of the tax system. Good governance breeds a fair and balanced tax system and equally a good tax system allows for quality governance. Good governance and effective tax systems positively influence tax revenue mobilization and tax compliance.

Everest-Phillip and Sandall (2009) argued that good public governance necessitates a good tax system, and a good tax system necessitates good public governance. Citizens assist the government in fulfilling its responsibilities by providing financial support in the form of tax payments. The taxpayers should be concerned about what is going on in the government since they are the ones who fund it. As a result, governance issues may have either a beneficial or negative impact on taxpayer compliance behavior.

Levi (1988) claimed that tax compliance is influenced by vertical contract when examining the connection between taxpayers and the government. He describes the relationship between taxpayers and the government as a vertical contract or quid pro quo of taxes. The vertical contract examines whether taxpayers receive public goods in exchange for their taxes. Compliance with tax law provisions, according to the quid pro quo argument, is contingent in part on whether the government's political goods are sufficient in exchange for the taxes paid (Lassen, 2003). Besancon (2003) agreed with Levi (1988) that there is a social compact between the government (ruler) and the taxpayers (ruled) that embodies the effective delivery of political goods. In addition, in line with Alm, McClelland, and Schulze (1992), Lassen (2003) stated that the political goods mix supplied by the government is also important and that if the political goods mix supplied by the government is very different from those they prefer, or if the rate of transformation is low due to corruption, taxpayers may feel the attractiveness of the quid pro quo contract is diminished, and that this could lead to litigation. Torgler (2003) argued that when the government's integrity is compromised, individuals' tax compliance may be crowded out since the government fails to honor his honesty. He went on to say that the government's good activities may lead to taxpayers developing favorable attitudes and dedication to the tax system and tax payment, resulting in increased compliance behavior. Mann and 
Johnson, P.N., Omodero, C.O., (2021)

Governance Quality and Tax Revenue Mobilization in Nigeria

Smith (1988) also claimed that when it comes to tax compliance, people are aware of their exchange relationship with the government.

Everst-Philips and Sandall (2009) examined the relationship between public governance quality and compliance further, noting that there is a link between public governance quality and taxation, with quality governance delivering a good tax system and a better tax system making it possible to have good governance. According to Akpo (2009), successful governance requires the provision of highquality public goods to the public, and citizens may become hesitant to pay taxes if the government fails to deliver public amenities and infrastructure in exchange for tax payments. Alm and Gomez (2008) found a significant positive relationship between taxpayers' desire to comply with tax regulations and their sense of the advantages to be received from political goods.

There are signs in Nigeria that the quality of public governance is not up to par. According to Natufe (2006), Nigeria is experiencing a fundamental crisis in public governance. The condition of decay in Nigeria's public infrastructure and economic activities, according to Abati (2006), is a manifestation of inadequate public governance. Religious and inter-ethnic strife, as well as deterioration in infrastructures such as education, power, health, and roads, are all indices and symptoms of Nigeria's weak public governance (Natufe, 2006). Madueke (2008) found widespread dissatisfaction with the quality of Nigerian public governance, blaming the problem on a lack of corruption control, a lack of rule of law, and poorly stated government policies. Lewis (2006) and Lewis \& Alemika (2005) investigations found a decrease in public satisfaction with government performance and democratic dividends in Nigeria. Fagbadebo (2007) also stated that Nigeria is a victim of bad public governance and that in order to promote effective public governance in Nigeria, accountability and transparency must be assured, transparency must be guaranteed to ensure good public governance in Nigeria.

\subsubsection{Corruption and Tax Revenue Mobilisation}

Corruption is usually defined as, the misuse of public office for personal advantage (Rodriguez et al., 2005). (Rodriguez et al., 2005). The World Bank has considered corruption to be the main hindrance to the socio-economic growth of the state. "In too many countries, people are deprived of their most basic needs and go to bed hungry every night because of corruption, while the powerful and corrupt live lavish lifestyles with impunity," says José Ugaz, Chair of Transparency International (Transparency International, 2016). Corruption has begun to gain traction as a research topic in emerging countries' academic literature. According to previous studies, defining corruption in its true sense is difficult. However, it is a well-known truth that its effects on the development of the state are corrosive (Tanzi, 2008). People are getting more concerned about the extent of corruption as their awareness

12 Journal of Legal Studies Volume 28 Issue 42/2021

$\checkmark$ sciendo ISSN 2457-9017; Online ISSN 2392-7054.

Web: publicatii.uvvg.ro/index.php/jls. Pages $1-41$ 
Johnson, P.N., Omodero, C.O., (2021)

Governance Quality and Tax Revenue Mobilization in Nigeria

grows among the general public (Pulok \& Ahmed, 2015). Past research has revealed that corruption has damaging repercussions for economic growth and human capital formation. It exacerbates poverty and causes public and private sector dysfunction. Corruption is a big issue in developing countries, where government officials utilize public funds for personal benefit. These countries are unable to earn sufficient money through taxation due to corruption in tax administration during the revenue collection process. Because of a lack of rule of law and governance accountability, corruption in the tax administration is on the rise (Abed \& Gupta, 2002). In addition, political unrest in developing countries reduces tax revenue generation and impedes economic growth and development. In this sense, the overall quality of governance is a vital aspect in any country's growth process lower taxation levels, according to Attila (2008) and Tanzi \& Davoodi (2000), are the outcome of ineffective tax systems caused by corruption. Tax compliance is eroded by corruption in the public sector, which leads to increased tax evasion (Djumashev, 2007; Joulfaian, 2009; Fjeldstad, 2005; Torgler, 2004; Alm \& Martinez-Vazquez, 2003). As a result, a country's ability to fund government spending is harmed. Similarly, because corruption diminishes tax collection's distributive function, it contributes to increased economic disparity. According to certain research (for example, Torgler, 2004; Gupta et al., 2002), corruption is linked to poverty. In general, the costs of corruption in Africa are extremely significant. It lowers government revenues by encouraging tax evasion and providing incentives to pay taxes, leaving less money for infrastructure, health care, and education spending.

Corruption becomes a threat to the state and a barrier to the market's proper operation. The government's effort to remove corruption is predicted to affect taxpayers' obedience. Institutional corruption is not unique to many developing countries, and it is prevalent in tax and customs administration. The government's many strategies and initiatives to combat tax leaks. The determination to eliminate corruption becomes a major source of energy for investment, particularly foreign investment. Ahsan and Wu (2005), Imam and Jacobs (2007), Gupta (2007), Bird, Vaquez and Torgler (2008), Mukhlis, Sugeng and Yuli (2014), and Syadulah and Wibowo (2015) studied the effects of corruption on tax revenues and concluded that corruption control measures had a beneficial effect on tax revenues. Corruption increases people's skepticism. When people believe their taxes are being misappropriated, their willingness to pay them falls. Corruption control has a strong positive impact on the tax ratio. (Ahsan et al., 2005) (2017, Faslan). In a country where the system isn't working well, there's a lot of room for corruption. Taxpayers must deal with the tax authority on a regular basis. According to Imam and Davina (2007), the building system reduces face-to-face interactions between taxpayers and tax officers. Reduce interaction through online payments, strengthen the tax office's internal control system, and provide clear and transparent standard operational 
Johnson, P.N., Omodero, C.O., (2021)

Governance Quality and Tax Revenue Mobilization in Nigeria

procedures (SOP) for computation, payment, and complaint. Tax revenues are reduced as a result of corruption (Abed and Gupta, 2002)

\subsubsection{Political Instability and Tax Revenue Mobilisation}

Given Nigeria's ongoing political turmoil, ethnic conflict, and religious violence, it is thought appropriate to look at the impact of political stability as an institutional factor alongside economic factors like the share of agriculture in GDP, trade openness, industry share in GDP, and inflation on tax revenue. Nigeria's political climate is a source of concern for the international world, owing to a series of preand post-election violence, ethnic militia crises, and religious divisions that have plagued the country over time. Institutional challenges and weak governance in developing nations, as well as poor policy formulation and implementation, corruption, and political instability, according to Amin, Nadeem, Parveen, Kamran, and Anwar (2014), are primary causes of the political challenge. Political crises impair the primary wheel that drives a country's economic development. The damaging mechanism that has harmed the economic progress of developing countries in Africa, Asia, America, and other continents is bad leadership with an unpatriotic mindset in government. Political stability, trade openness, per capita income, and reducing inflation are all factors that influence tax revenue growth. Trade openness eliminates the quantitative barrier to products and services, resulting in increased tax income (Amin et al.,2014). Because it has a large amount of foreign trade, an open economy is thought to be well-established and well-planned. Because of its impact on the cost of goods and services, inflation is predicted to have a negative impact on tax revenue collection.

Political stability (PS) is said to affect the tax-to-GDP ratio significantly. The more the political tension and the likelihood of a terrorist attack, the lower the tax collection will invariably be (Ajaz and Ahmad, 2010). This is in line with theoretical models developed by Cukierman, Edwards, and Tabellini (1991), which are quoted by Syadullah and Wibowo (2015), in which political instability and polarization dictate the equilibrium effectiveness of the tax system and the arrangement induced by tax revenues.

\subsubsection{Bad governance and Tax Revenue Mobilisation}

The incentives for engaging in corrupt activity in the public sector are twofold: first, government officials who want to enrich themselves by accepting bribes, and second, bribe payers who wish to get unfair benefits through tax fraud. The complexity of the tax system encourages public officials to use their administrative power, which leads to an increase in corruption (Ajaz and Ahmed 2010). In the following words, Sandmo (2004) employs the concept of tax avoidance. "Tax evasion is a legal violation: When a taxpayer fails to declare income from labor or capital that is

14 Journal of Legal Studies Volume 28 Issue 42/2021

$\checkmark$ sciendo ISSN 2457-9017; Online ISSN 2392-7054.

Web: publicatii.uvvg.ro/index.php/jls. Pages $1-41$ 
Johnson, P.N., Omodero, C.O., (2021)

Governance Quality and Tax Revenue Mobilization in Nigeria

primarily taxable, he engages in an illegal conduct that subjects him to administrative or judicial action by the authorities." What counts is not just how high the taxes are (revenue sufficiency), but also how the tax level was determined, how the taxes were enforced, and how the revenues obtained were spent. In democratic states, tax issues are dealt through political means. Indeed, history suggests that obtaining a sufficient level of consensus from the taxed is one of the primary ways in which democratic institutions have spread over the years. State legitimacy is thus based to a large measure on citizens' "quasivoluntary acquiescence" with taxation (Levi, 1988). To ensure compliance, tax systems must, over time, reflect the fundamental values of at least a small supporting coalition of the population. The fundamental foundations for a healthy tax system are good governance, state legitimacy, taxpayers' willingness to pay taxes, and the effectiveness of tax administration. The relationship between governance and tax reforms is described by Phillips and Sandali (2008). According to the study, the interaction between governance, taxation, and investment climate is reflected in three important dynamics. Better governance allows for the creation of a good and investment-friendly tax regime that promotes economic growth.

\subsection{Theoretical Framework}

\subsubsection{Fiscal Exchange Theory}

Buchanan J.M. proposed fiscal exchange theory in his 1976 research, Taxation in Fiscal Exchange, to show that the two sides of the fiscal account (taxes and expenditure) must be evaluated simultaneously and from the perspective of the political framework. The fiscal exchange hypothesis is based on the premise that government expenditure is an important instrument for motivating people to pay their taxes. The government can generate more revenue by investing in delivering goods and services that citizens require in an efficient and accessible manner. According to Syadullah \& Wibowo (2015), when the provision of goods and services improves, tax revenue will increase as a result of compliance. Citizens would like to pay taxes in exchange for public amenities that they value since they are concerned about what they will receive in return for the levy they pay. The presence of positive advantages can improve the likelihood of the taxpayer happily complying.

Tax collectors corruption affects taxpayers' unwillingness to pay taxes, which contradicts the belief that taxpayers are unwilling to pay taxes, resulting in the decision to employ force (Lien, 2015). Several factors influence taxpayers' attitudes toward paying taxes, including the presence of tax morality, often known as the ethical component, which arises from good governance. According to Imam and Jacobs (2007), tax revenue production is solely the responsibility of tax administrators, and collection can be aided by excellent governance carried out by the executive branch of government. 
Johnson, P.N., Omodero, C.O., (2021)

Governance Quality and Tax Revenue Mobilization in Nigeria

The fiscal exchange hypothesis proposes that tax income is inspired by government expenditure, according to Fjeldstad, Collette, and Ingrid (2012); Moore (2004). This argument is deeply founded in economics and political science. With the construction of infrastructure, tax compliance improves. The greater the availability and accessibility of products and services that citizens require, the more willing taxpayers are to pay taxes. The reception of public goods and services is also proof of the government's need for tax income (Alm, Jackson \&Mckee, 1992). Taxpayers' primary concern is the benefit they receive in the form of public goods in exchange for their tax payment (quid pro quo).

From the standpoint of taxpayers, the supply of public goods and services is viewed as a contractual arrangement between them and the government, because taxpayers' interest is in what they receive from the government in exchange for what they pay in taxes (Fjeldstad et al., 2012). This idea can also be considered to make tax payments conditional on the government's performance in providing essential goods and services. Taxpayers consider their tax payments as exchanging purchasing power for government products and services in the market. According to Fjeldstad et al. (2012), the presence of favorable benefits is likely to increase the likelihood of voluntary compliance by taxpayers, resulting in a positive impact on tax revenue, because it entails citizens and businesses receiving goods and services from the government in exchange for the government extracting money from them. Government performance, honesty, effectiveness, responsiveness to due process, and government reliability, according to Fjeldstad et al. (2012), all influence the degree of tax compliance, as compliance declines without a material benefit, even though the exact value of the benefit received in exchange for tax payment from the government cannot be quantified. It can be claimed that the amount of tax money obtained by the government has something to do with how satisfied or dissatisfied taxpayers are with the government's terms of trade. It indicates that if individuals have a fair perspective of government activities, tax evasion will invariably be at a low ebb, as citizens will adapt their actions in accordance with the terms of trade with the government.

Establishing and improving good governance is an executive task that can have a favorable impact on tax income. The elements that influence tax morality, according to Alm and Torgler (2011), are trust in government, fair tax administration, nationalism, and democracy. The fiscal exchange theory, which states that government spending is an impulse to elicit voluntary tax compliance by taxpayers, is the study's fundamental theory. The idea stresses citizens' attitudes toward government spending as an important instrument for motivating tax compliance. The government can generate money by spending on goods and services that are necessary to citizens and are well-organized and accessible. 
Johnson, P.N., Omodero, C.O., (2021)

Governance Quality and Tax Revenue Mobilization in Nigeria

\subsubsection{Social Exchange theory}

Human interactions and trades are viewed as a type of results-driven social activity in the theory of social exchange. The cost and reward concept is central to the theory of social exchange. This means that cost and reward comparisons influence human decisions and behavior, and that diverse social exchanges interact with the government to address inefficiencies. By demonstrating how the government's incompetence and disregard for the social compact cause businesses to be less willing to comply with tax compliance obligations.

According to previous studies, people expect the government to offer services and benefits in exchange for their taxes (Kim, 2002; Wenzel, 2003). When it comes to corporate tax revenue mobilization, this means that businesses will pay taxes if they perceive they are getting value for their money. Bribery, for example, is widely regarded as an unjust and costly cost of doing business (Litina \& Palivos, 2016). Because a corruption-free corporate climate is part of the social contract that governments should respect, the prevalence of bribery would imply a breach of the social contract, tarnishing the firm-government social exchange relationship. Similarly, in a healthy business environment, the tax system is anticipated to be reasonable, with tax rates that are not unduly costly for enterprises. The social contract is disrupted by a complex and expensive tax regime, which tilts the scales against businesses in the social trade. We argue that firms will be less tolerant of inefficiencies in government service and more reluctant to comply with tax compliance requirements as a result of this broken trust in the government. Social exchange captures a broader dynamic in which norms and concerns about fairness moderate how the main economic exchange is perceived and the extent to which retaliation occurs.

\subsection{Empirical Framework}

Table 1. Summary of Empirical literature reviewed

\begin{tabular}{|c|l|l|l|l|l|l|}
\hline $\begin{array}{c}\mathrm{S} \\
/ \\
\mathrm{N}\end{array}$ & Authors & Year & $\begin{array}{l}\text { Sample size or } \\
\text { scope }\end{array}$ & $\begin{array}{l}\text { Purpose of the } \\
\text { Study }\end{array}$ & Methodology & Result \\
\hline 1. & Hassan et al & 2021 & $\begin{array}{l}\text { This study } \\
\text { covers the } \\
\text { period from } \\
1976 \text { to 2019 }\end{array}$ & $\begin{array}{l}\text { The purpose of } \\
\text { this study is to } \\
\text { look into the } \\
\text { effects of } \\
\text { governance on } \\
\text { tax revenue in } \\
\text { Pakistan, } \\
\text { utilizing } \\
\text { inflation and } \\
\text { industrial value- } \\
\text { added as control } \\
\text { variables. }\end{array}$ & $\begin{array}{l}\text { Auto- } \\
\text { regressive } \\
\text { Distribution } \\
\text { Lag }\end{array}$ & $\begin{array}{l}\text { The findings } \\
\text { revealed that } \\
\text { in the long and } \\
\text { short run, } \\
\text { government } \\
\text { stability, law } \\
\text { and order, and } \\
\text { internal and } \\
\text { external } \\
\text { conflict have a } \\
\text { positive and } \\
\text { considerable }\end{array}$ \\
\hline
\end{tabular}


Johnson, P.N., Omodero, C.O., (2021)

Governance Quality and Tax Revenue Mobilization in Nigeria

\begin{tabular}{|c|c|c|c|c|c|c|}
\hline $\begin{array}{l}\mathrm{S} \\
/ \\
\mathrm{N}\end{array}$ & Authors & Year & $\begin{array}{l}\text { Sample size or } \\
\text { scope }\end{array}$ & $\begin{array}{l}\text { Purpose of the } \\
\text { Study }\end{array}$ & Methodology & Result \\
\hline & & & & & & $\begin{array}{l}\text { impact on tax } \\
\text { income. }\end{array}$ \\
\hline 2. & $\begin{array}{l}\text { Dibie } \quad \& \\
\text { Dibie }\end{array}$ & 2020 & $\begin{array}{l}\text { This study } \\
\text { made use of } \\
\text { primary data } \\
\text { from } \\
\text { interviews and } \\
\text { questionnaires } \\
\text { A total of } \\
5000 \\
\text { questionnaires } \\
\text { were } \\
\text { administered } \\
\text { to the citizens }\end{array}$ & $\begin{array}{l}\text { The purpose of } \\
\text { the study is to } \\
\text { determine if } \\
\text { there's a positive } \\
\text { relationship } \\
\text { between } \\
\text { corruption and } \\
\text { tax compliance }\end{array}$ & $\begin{array}{l}\text { SPSS } \\
\text { statistical tool }\end{array}$ & $\begin{array}{l}\text { The study } \\
\text { reveals that } \\
\text { there is a } \\
\text { strong positive } \\
\text { correlation } \\
\text { between } \\
\text { corruption and } \\
\text { tax evasion. }\end{array}$ \\
\hline 3. & Mallick & 2020 & $\begin{array}{l}\text { Centre, States } \\
\text { and Union } \\
\text { Territories of } \\
\text { India during } \\
\text { the post- } \\
\text { liberalization } \\
\text { period of } \\
\text { 1990-1991 to } \\
2017-2018 \text {. }\end{array}$ & $\begin{array}{l}\text { It attempts to } \\
\text { empirically } \\
\text { understand the } \\
\text { role of } \\
\text { Information and } \\
\text { Communication } \\
\text { Technology } \\
\text { infrastructure } \\
\text { and governance } \\
\text { quality in direct } \\
\text { and indirect tax } \\
\text { revenues } \\
\text { mobilization for } \\
\text { the combined } \\
\text { governments of } \\
\text { Centre, States } \\
\text { and Union } \\
\text { Territories of } \\
\text { India }\end{array}$ & $\begin{array}{l}\text { Regression } \\
\text { Analysis }\end{array}$ & $\begin{array}{l}\text { The findings } \\
\text { surprisingly } \\
\text { reveal that } \\
\text { ICT } \\
\text { infrastructures } \\
\text { and } \\
\text { governance } \\
\text { quality have } \\
\text { no significant } \\
\text { positive effect } \\
\text { on the overall } \\
\text { tax revenue } \\
\text { collections. }\end{array}$ \\
\hline 4. & $\begin{array}{l}\text { Akintoye, } \\
\text { Adegbie \& } \\
\text { Awotomi- } \\
\text { lusi }\end{array}$ & 2019 & $\begin{array}{l}\text { This study } \\
\text { covers the } \\
\text { period } 1984 \text { to } \\
2017\end{array}$ & $\begin{array}{l}\text { The study } \\
\text { looked at the } \\
\text { impact of } \\
\text { political } \\
\text { stability and the } \\
\text { lack of violence } \\
\text { as institutional } \\
\text { factors on tax } \\
\text { revenue in } \\
\text { Nigeria, as well } \\
\text { as economic } \\
\text { parameters } \\
\text { including }\end{array}$ & $\begin{array}{l}\text { Auto- } \\
\text { regressive } \\
\text { distribution } \\
\text { lag }\end{array}$ & $\begin{array}{l}\text { The study } \\
\text { found a link } \\
\text { between } \\
\text { political } \\
\text { stability and } \\
\text { the absence of } \\
\text { violence/ } \\
\text { terrorism and } \\
\text { tax revenue, } \\
\text { which is } \\
\text { consistent } \\
\text { with } \\
\text { expectations. }\end{array}$ \\
\hline
\end{tabular}


Johnson, P.N., Omodero, C.O., (2021)

Governance Quality and Tax Revenue Mobilization in Nigeria

\begin{tabular}{|c|c|c|c|c|c|c|}
\hline $\begin{array}{l}\mathrm{S} \\
/ \\
\mathrm{N}\end{array}$ & Authors & Year & $\begin{array}{l}\text { Sample size or } \\
\text { scope }\end{array}$ & $\begin{array}{l}\text { Purpose of the } \\
\text { Study }\end{array}$ & Methodology & Result \\
\hline & & & & $\begin{array}{l}\text { industry share in } \\
\text { GDP, } \\
\text { agriculture share } \\
\text { in GDP, trade } \\
\text { openness, and } \\
\text { inflation } \\
\text { control } \\
\text { variables. }\end{array}$ & & \\
\hline 5. & Umar et al & 2019 & & $\begin{array}{l}\text { The goal of this } \\
\text { study is to look } \\
\text { into the } \\
\text { relationship } \\
\text { between public } \\
\text { governance } \\
\text { quality and tax } \\
\text { compliance } \\
\text { behavior } \\
\text { developing in } \\
\text { nations, } \\
\text { specifically in } \\
\text { terms of what } \\
\text { happens } \\
\text { between } \\
\text { governments } \\
\text { and individuals } \\
\text { that causes them } \\
\text { to pay or not pay } \\
\text { tax. }\end{array}$ & $\begin{array}{l}\text { This study } \\
\text { takes } \\
\text { conceptual a } \\
\text { approach and } \\
\text { uses a } \\
\text { synthesis of } \\
\text { literature and } \\
\text { past research } \\
\text { findings to } \\
\text { connect the } \\
\text { concepts. }\end{array}$ & $\begin{array}{l}\text { The study } \\
\text { concludes that } \\
\text { socio- } \\
\text { economic } \\
\text { condition } \\
\text { mediates the } \\
\text { relationship } \\
\text { between } \\
\text { public } \\
\text { governance } \\
\text { quality and tax } \\
\text { compliance } \\
\text { behavior in } \\
\text { developing } \\
\text { countries. } \\
\text { Socio- } \\
\text { economic } \\
\text { conditions } \\
\text { appear to be a } \\
\text { broader, } \\
\text { clearer and } \\
\text { more practical } \\
\text { concept for } \\
\text { measurement } \\
\text { purposes than } \\
\text { public goods/ } \\
\text { spending as } \\
\text { currently } \\
\text { understood in } \\
\text { the literature. }\end{array}$ \\
\hline 6. & $\begin{array}{l}\text { Djayasinga } \\
\text { \& Prasetyo }\end{array}$ & 2019 & $\begin{array}{l}\text { The study } \\
\text { covers the } \\
\text { period } \\
\text { between } 2002 \\
\text { and 2014 }\end{array}$ & $\begin{array}{l}\text { The goal of this } \\
\text { study is to look } \\
\text { into the } \\
\text { connection } \\
\text { between } \\
\text { government } \\
\text { effectiveness, } \\
\text { rule of law, and }\end{array}$ & $\begin{array}{l}\text { Fixed effect } \\
\text { model }\end{array}$ & $\begin{array}{l}\text { There was } \\
\text { found } \\
\text { evidence that } \\
\text { the rule of law } \\
\text { and control of } \\
\text { corruption } \\
\text { drastically } \\
\text { influence tax }\end{array}$ \\
\hline
\end{tabular}


Johnson, P.N., Omodero, C.O., (2021)

Governance Quality and Tax Revenue Mobilization in Nigeria

\begin{tabular}{|c|c|c|c|c|c|c|}
\hline $\begin{array}{l}\mathrm{S} \\
/ \\
\mathrm{N}\end{array}$ & Authors & Year & $\begin{array}{l}\text { Sample size or } \\
\text { scope }\end{array}$ & $\begin{array}{l}\text { Purpose of the } \\
\text { Study }\end{array}$ & Methodology & Result \\
\hline & & & & $\begin{array}{l}\text { corruption } \\
\text { control as a set } \\
\text { of strong } \\
\text { government } \\
\text { governance and } \\
\text { tax compliance. }\end{array}$ & & $\begin{array}{l}\text { obedience. } \\
\text { The } \\
\text { effectiveness } \\
\text { of the } \\
\text { government, } \\
\text { on the other } \\
\text { hand, has no } \\
\text { bearing on tax } \\
\text { compliance. }\end{array}$ \\
\hline 7. & 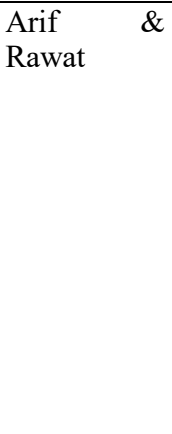 & 2018 & $\begin{array}{l}\text { The study } \\
\text { covers } \\
\text { period of } 15 \\
\text { years; from } \\
2001 \text { to } 2015\end{array}$ & $\begin{array}{l}\text { The study's goal } \\
\text { is to answer the } \\
\text { question, "What } \\
\text { are the } \\
\text { consequences of } \\
\text { corruption and } \\
\text { governance } \\
\text { quality } \\
\text { EAGLE on } \\
\text { countries' tax } \\
\text { income } \\
\text { generation?" }\end{array}$ & $\begin{array}{l}\text { Pooled Mean } \\
\text { Group } \\
\text { estimation }\end{array}$ & $\begin{array}{l}\text { The findings } \\
\text { revealed that } \\
\text { corruption and } \\
\text { governance } \\
\text { have a } \\
\text { favorable and } \\
\text { considerable } \\
\text { impact on } \\
\text { emerging } \\
\text { economies' } \\
\text { tax revenue } \\
\text { collection. }\end{array}$ \\
\hline 8. & $\begin{array}{l}\text { Epaphra \& } \\
\text { Massawe }\end{array}$ & 2017 & $\begin{array}{l}\text { The study } \\
\text { covers } \\
\text { African } \\
\text { countries over } \\
\text { the } 1996 \text { to } \\
2016 \text { period }\end{array}$ & $\begin{array}{l}\text { It investigates } \\
\text { the impact of } \\
\text { institutional, } \\
\text { structural and } \\
\text { policy variables } \\
\text { on tax revenue }\end{array}$ & $\begin{array}{l}\text { Fixed effect } \\
\text { and Random } \\
\text { effect models }\end{array}$ & $\begin{array}{l}\text { The findings } \\
\text { suggest that } \\
\text { governments } \\
\text { should } \\
\text { minimize } \\
\text { corruption, } \\
\text { enhance tax } \\
\text { and customs } \\
\text { administration } \\
\text {, and increase } \\
\text { revenue from } \\
\text { tax categories } \\
\text { that are less } \\
\text { prone to } \\
\text { corruption in } \\
\text { order to earn } \\
\text { more tax } \\
\text { revenue. They } \\
\text { should also } \\
\text { improve trade } \\
\text { transparency. }\end{array}$ \\
\hline 9. & Chariye & 2016 & $\begin{array}{l}\text { The study } \\
\text { covers } \\
\text { profit } \\
\text { taxpayers in }\end{array}$ & $\begin{array}{l}\text { The overall goal } \\
\text { of this research } \\
\text { is to see how } \\
\text { corruption }\end{array}$ & $\begin{array}{l}\text { Ordered probit } \\
\text { model }\end{array}$ & $\begin{array}{l}\text { According to } \\
\text { the study, at } \\
\text { the } 5 \% \\
\text { significance }\end{array}$ \\
\hline
\end{tabular}


Johnson, P.N., Omodero, C.O., (2021)

Governance Quality and Tax Revenue Mobilization in Nigeria

\begin{tabular}{|c|c|c|c|c|c|c|}
\hline $\begin{array}{l}\mathrm{S} \\
/ \\
\mathrm{N}\end{array}$ & Authors & Year & $\begin{array}{l}\text { Sample size or } \\
\text { scope }\end{array}$ & $\begin{array}{l}\text { Purpose of the } \\
\text { Study }\end{array}$ & Methodology & Result \\
\hline & & & $\begin{array}{l}\text { Addis Ababa } \\
\text { City } \\
\text { Administra- } \\
\text { tion. }\end{array}$ & $\begin{array}{ll}\text { affects } & \text { tax } \\
\text { morale. } & \end{array}$ & & $\begin{array}{l}\text { level, tax } \\
\text { morale } \\
\text { (dependent } \\
\text { variable) is } \\
\text { connected } \\
\text { with the } \\
\text { corruption at - } \\
0.3093 \text {, and } \\
\text { there is a } \\
\text { significant } \\
\text { negative } \\
\text { association } \\
\text { between } \\
\text { corruption and } \\
\text { tax morale at a } \\
\text { p value of } \\
0.048 \text {. }\end{array}$ \\
\hline 10 & Lien & 2014 & $\begin{array}{l}\text { This study } \\
\text { covers the } \\
\text { period from } \\
1996 \text { to } 2013\end{array}$ & $\begin{array}{l}\text { Over the period } \\
\text { 1996-2013, } \\
\text { assess the } \\
\text { influence of } \\
\text { experimental } \\
\text { institutional } \\
\text { quality on tax } \\
\text { revenues for an } \\
\text { overall sample } \\
\text { of eighty-two } \\
\text { developing } \\
\text { nations and } \\
\text { compare this } \\
\text { influence across } \\
\text { three economic } \\
\text { groups: low- } \\
\text { income, lower- } \\
\text { middle, and } \\
\text { upper-middle- } \\
\text { income. }\end{array}$ & $\begin{array}{l}\text { Difference } \\
\text { panel GMM }\end{array}$ & $\begin{array}{l}\text { The findings } \\
\text { reveal that } \\
\text { institutional } \\
\text { quality has a } \\
\text { considerably } \\
\text { beneficial } \\
\text { impact on tax } \\
\text { revenue in the } \\
\text { entire sample, } \\
\text { as well as in } \\
\text { the low- } \\
\text { income and } \\
\text { lower-middle- } \\
\text { income } \\
\text { groups, while } \\
\text { it has a } \\
\text { significantly } \\
\text { negative } \\
\text { influence in } \\
\text { the upper- } \\
\text { middle- } \\
\text { income group. }\end{array}$ \\
\hline 11 & Hossain & 2014 & $\begin{array}{l}\text { This study } \\
\text { covers the } \\
\text { period from } \\
2002 \text { to } 2012\end{array}$ & $\begin{array}{l}\text { The main } \\
\text { purpose of this } \\
\text { paper is to } \\
\text { justify whether } \\
\text { the quality of } \\
\text { governance } \\
\text { (better }\end{array}$ & $\begin{array}{l}\text { Fixed effect } \\
\text { and Random } \\
\text { effect model }\end{array}$ & $\begin{array}{l}\text { The study's } \\
\text { findings show } \\
\text { that } \\
\text { governance } \\
\text { quality affects } \\
\text { tax revenue } \\
\text { collection, and }\end{array}$ \\
\hline
\end{tabular}


Johnson, P.N., Omodero, C.O., (2021)

Governance Quality and Tax Revenue Mobilization in Nigeria

\begin{tabular}{|c|c|c|c|c|c|c|}
\hline $\begin{array}{l}\mathrm{S} \\
/ \\
\mathrm{N}\end{array}$ & Authors & Year & $\begin{array}{l}\text { Sample size or } \\
\text { scope }\end{array}$ & $\begin{array}{l}\text { Purpose of the } \\
\text { Study }\end{array}$ & Methodology & Result \\
\hline & & & & $\begin{array}{l}\text { institution and } \\
\text { low corruption) } \\
\text { leads to a higher } \\
\text { tax effort. }\end{array}$ & & $\begin{array}{l}\text { the findings } \\
\text { support the } \\
\text { notion that } \\
\text { more } \\
\text { institutional } \\
\text { capability and } \\
\text { lower } \\
\text { corruption } \\
\text { increase tax } \\
\text { revenue in the } \\
\text { economy. }\end{array}$ \\
\hline 12 & $\begin{array}{l}\text { Alabede, } \\
\text { Ariffin } \quad \& \\
\text { Idris }\end{array}$ & 2011 & & $\begin{array}{l}\text { To explore } \\
\text { whether the } \\
\text { relationship } \\
\text { between } \\
\text { taxpayers' } \\
\text { perceptions of } \\
\text { public } \\
\text { governance } \\
\text { quality and their } \\
\text { compliance } \\
\text { behavior is } \\
\text { influenced by } \\
\text { financial status } \\
\text { and risk choice } \\
\text { separately and } \\
\text { together. }\end{array}$ & $\begin{array}{l}\text { Moderated } \\
\text { Multiple } \\
\text { regression }\end{array}$ & $\begin{array}{l}\text { The study's } \\
\text { main finding } \\
\text { is that the } \\
\text { quality of } \\
\text { government } \\
\text { has } \\
\text { substantial } \\
\text { positive link } \\
\text { with tax } \\
\text { compliance } \\
\text { behavior. Risk } \\
\text { preference has } \\
\text { a considerable } \\
\text { negative } \\
\text { moderating } \\
\text { influence on } \\
\text { the connection } \\
\text { between } \\
\text { public } \\
\text { governance } \\
\text { effectiveness } \\
\text { and tax } \\
\text { compliance } \\
\text { behavior, } \\
\text { according to } \\
\text { the study. }\end{array}$ \\
\hline
\end{tabular}

\section{Research methodology}

\subsection{Research Design}

The framework of research methods and techniques designed to answer research questions or test hypotheses in a study is known as research design. It is very significant in a research process because it determines how relevant information will be obtained throughout the study. 
Johnson, P.N., Omodero, C.O., (2021)

Governance Quality and Tax Revenue Mobilization in Nigeria

This study uses an ex-post facto research design to quantify the impact of governance quality on tax revenue mobilization effectively. The expo-facto research design is used when the phenomena being studied have already occurred. Henry (2019) noted that an ex post facto research design is appropriate in investigating a cause-and-effect relationship between the dependent variable (tax revenue mobilization) and independent variables (corruption, political instability and bad governance) when randomization or alteration of the independent variable is not possible. This research design was chosen because the data needed for this research is already existing from information in annual reports, statistical bulletins and statements in the database of Federal Inland Revenue Service, Economic Quarterly, International Center of Tax and Development (ICTD) database, World Governance indicators of World Bank and World Development Indicators of World Bank. Therefore, it is appropriate for the study.

\subsection{Sources of Data}

This study will use secondary data sources for collecting necessary information useful for governance quality and tax performance in Nigeria. The choice of secondary data is benchmarked on availability and accessibility of the required data pool from published information in annual reports, statistical bulletins and statements in the database of Federal Inland Revenue Service, Economic Quarterly, International Center of Tax and Development (ICTD) database, World Governance indicators of World Bank and World Development Indicators of World Bank. The secondary data for this study spans the period between 2000 and 2020 .

\subsection{Measurement of Variables Dependent Variable}

This study proxies tax revenue by the total tax revenue expressed in the percentage of gross domestic product.

\section{Independent Variable}

The governance quality will be derived from the World Governance Indicators of the World Bank. This will include corruption control, rule of law and voice \&Accountability.

\section{Control Variable}

The study will include a battery of control variables to account for omitted variables, namely, inflation, agriculture share in GDP and population growth. It is expected that these variables tend to influence the level of government revenue.

\subsection{Model Specification}

This study will investigate the nexus between governance quality and tax revenue performance in Nigeria from 2000-2020. 
Johnson, P.N., Omodero, C.O., (2021)

Governance Quality and Tax Revenue Mobilization in Nigeria

Below is the implicit model for this study:

$Y_{t}=\beta_{0}+\beta_{1} X_{t}+\varepsilon_{t}$

Where $Y$ is the dependent variable. And $X$ is the explanatory variable. In furtherance of the earlier model, the following includes the explicit model for this study:

The model specification is expressed as follows:

Tax $_{i}=\beta_{o}+\beta_{1} C P I_{t}+\beta_{2}$ Insecurity $_{t}+\beta_{3}$ Umep $_{t}+\varepsilon_{t}$

Table 2. Definition of Variables

\begin{tabular}{|c|c|c|c|}
\hline Variables & Definitions & Acronym & Sources \\
\hline \multicolumn{4}{|l|}{$\begin{array}{l}\text { Dependent } \\
\text { Variables }\end{array}$} \\
\hline Tax revenue & $\begin{array}{l}\text { Total taxes revenue excluding } \\
\text { social contributions }\end{array}$ & TAX & FIRS/GRD \\
\hline \multicolumn{4}{|c|}{ Independent variables } \\
\hline \multicolumn{4}{|c|}{ Governance Quality } \\
\hline $\begin{array}{l}\text { Corruption } \\
\text { Perception } \\
\text { Index }\end{array}$ & $\begin{array}{l}\text { Perceptions of the extent to } \\
\text { which public power is } \\
\text { exercised for private gain }\end{array}$ & CPI & WGI \\
\hline $\begin{array}{l}\text { Political } \\
\text { Instability }\end{array}$ & $\begin{array}{l}\text { Perceptions of the extent to } \\
\text { which policies and actions of } \\
\text { government fluctuate }\end{array}$ & INSECURITY & WGI \\
\hline $\begin{array}{l}\text { Bad } \\
\text { Governance }\end{array}$ & $\begin{array}{l}\text { The extent to which a country's } \\
\text { government is negative }\end{array}$ & UNEMP & ILO \\
\hline
\end{tabular}

Note: FIRS - Federal Inland Revenue Service; GRD - ICTD Government Revenue Database; WGI - World Governance Indicators.

\subsection{Method of Data Analysis}

The descriptive statistics is firstly engaged to summarise the statistical characteristics of the data for this study. The descriptive features include the mean, median, mode, minimum. Maximum value, standard deviation, skewness, kurtosis among others. In order to validate the formulated hypotheses for this study, Autoregressive Distributed Lag Model (ARDL) will be adopted. The Model is developed by Pesaran\& Shin (1999), which is later expanded by Pesaran, Shin \& Smith (2001). The Autoregressive Distributed Lag Model (ARDL) has a couple of advantages (Shrestha, 2002; Unevska, 2007), which includes (i) the application of mixed integrated data that is the data being at the stationery $\mathrm{I}(0)$ or first difference $1(\mathrm{I})$; (ii) the concern of exogenous variables is facilitated; (iii) the short and long-run relationships are obtained by using the transforming the estimate from Ordinary 
Johnson, P.N., Omodero, C.O., (2021)

Governance Quality and Tax Revenue Mobilization in Nigeria

Least Square (OLS) to Autoregressive Distributed Lag Model (ARDL) with apposite lag length and; (iv) the model is relevant for small observations.

In addition, the procedure for Autoregressive Distributed Lag Model (ARDL) often requires four (4) steps such as (i) data stationarity via Unit Root Test; (ii) cointegration between variables for dynamics of a long and short-run; and (iii) diagnostic tests to validate the research model. The diagnostic Test includes serial correlation test, heteroskedasticity, residual normality, stability tests and recursive estimates of residuals. In essence, the initial step for Autoregressive Distributed Lag Model (ARDL) involves the determination of data non-stationarity. However, the Autoregressive Distributed Lag Model (ARDL) usage will be terminated if the order of the variables' integration exceeds One. Another reason to test for non-stationary data is that it prevents spurious regression effects, which is a common issue when using non-stationary data.

\section{Data analysis, results and discussion of findings}

This chapter gives a detailed presentation of the findings of this research on governance quality and tax revenue mobilization in Nigeria. The study was conducted in Nigeria where secondary data for the period 2000 to 2020 was used. Multiple linear regression confirms the influence of governance quality on tax revenue in Nigeria.

\subsection{Descriptive Analysis}

The information presented below in Table 4.1 shows the descriptive statistics for the variables in this research to examine tax revenue mobilization in Nigeria. The table represents the mean, maximum, minimum, standard deviation and observation number for each variable.

Table 3. Descriptive Analysis

\begin{tabular}{|c|c|c|c|c|}
\hline & \multicolumn{2}{|c|}{ TAX_REVENUE CPI } & INSECURITY & UNEMP \\
\hline Mean & 3.361615 & 1.332634 & 2.192272 & 4.898095 \\
\hline Median & 3.473078 & 1.397940 & 2.298221 & 3.820000 \\
\hline Maximum & 3.725984 & 1.447158 & 2.770107 & 9.010000 \\
\hline Minimum & 2.637390 & 1.000000 & 1.637513 & 3.590000 \\
\hline Std. Dev. & 0.365936 & 0.130102 & 0.394800 & 1.980703 \\
\hline Skewness & -0.844399 & -1.291045 & -0.004989 & 1.275179 \\
\hline Kurtosis & 2.386856 & 3.470019 & 1.415744 & 2.777863 \\
\hline Sum & 70.59392 & 27.98531 & 46.03772 & 102.8600 \\
\hline $\begin{array}{ll}\text { Sum } & \text { Sq. } \\
\text { Dev. }\end{array}$ & 2.678189 & 0.338530 & 3.117336 & 78.46372 \\
\hline Observations & 21 & 21 & 21 & 21 \\
\hline
\end{tabular}

Source: Author's Computation with the aid of Eviews 11 
Johnson, P.N., Omodero, C.O., (2021)

Governance Quality and Tax Revenue Mobilization in Nigeria

In the above table, the descriptive statistics of all operationalized variables in this research are well presented. The maximum value for the tax revenue was 3.725984 with a minimum value of 2.63 approximately. However, the maximum value for corruption, political instability and bad governance was shown at 1.447158 , 2.770107 and 9.01 respectively and their minimum values were shown at 1 , 1.637513 and 3.590000. Their standard deviations stood at $0.365936,0.130102$, 0.394800 and 1.980703 reveals that the individual observations did not deviate so much from their respective means of 3.361615, 1.332634, 2.192272, 4.898095 respectively. Also, the skewness estimate was used to reveal how well the variables from the generated sample revenue lean to one side of the distribution. Furthermore, it was observed that all the independent variables were negatively skewed and this indicates that the probability distribution of the means of the variables has thin tails to the left of the distribution.

The kurtosis value shown in table 4.1 above shows the peak or flatness of the distribution in the series shown in this study. The criteria used for this decision is placed at 3 , however, values greater than 3 are referred to as leptokurtic, values less than 3 are regarded as platykurtic while values that equate to 3 are called mesokurtic. Table 4.1 above shows that only the CPI result obtained from the variables is platykurtic with tax revenue having a kurtosis of 2.386856, corruption kurtosis being 3.470019 , insecurity expenditure having 1.415744 and rule of law has a kurtosis of 2.777863 .

\subsection{Correlation}

Correlation analysis is used to show the degree of relationship existing between governance quality and tax revenue mobilization which is the independent and dependent variable respectively. To further reveal the direction of the association of the variables in the research correlation analysis was conducted.

The Pearson correlation has been presented in the table below to measure the relationship between governance quality and tax revenue mobilization in Nigeria.

Table 3. Correlation Table

\begin{tabular}{|l|l|l|l|l|}
\hline & TAX_REVENUE & CPI & INSECURITY & UNEMP \\
\hline TAX_REVENUE & 1 & 0.909821 & 0.863629 & 0.480087 \\
\hline CPI & 0.909821 & 1 & 0.752809 & 0.400164 \\
\hline INSECURITY & 0.863629 & 0.752809 & 1 & 0.715218 \\
\hline UNEMP & 0.480087 & 0.400164 & 0.715218 & 1 \\
\hline
\end{tabular}

Source: Authors Computation with the aid of Eviews 11

$$
\begin{array}{ll} 
& \text { Journal of Legal Studies Volume 28 Issue 42/2021 } \\
\text { ISSN 2457-9017; Online ISSN 2392-7054. } \\
\text { Web: publicatii.uvvg.ro/index.php/jls. Pages } 1-41
\end{array}
$$


Johnson, P.N., Omodero, C.O., (2021)

Governance Quality and Tax Revenue Mobilization in Nigeria

The rule of statistics in general states that when correlation coefficients fall between 0 and 0.30 indicates a weak correlation, when it falls between 0.30 and 0.60 the correlation is said to be moderate, and correlation that lies between $0.60-1.00$ is a strong correlation. Table 4 shows the correlation between the proxies of governance quality and tax revenue in Nigeria. The correlation matrix shows that there is a positive relationship between corruption and tax revenue mobilization. This positive correlation was supported by a p-value of 0.909821 which implies that corruption was strongly correlated with tax revenue. Furthermore, the results showed that political instability proxied by insecurity expenditure is positively correlated with tax revenue and this positive correlation was supported by a p-value of 0.8636 . However, the result of this analysis revealed that bad governance proxied by the unemployment rate was moderately correlated with tax revenue. This could be that bad governance within a period has a moderate impact on the tax revenue of the country. This positive correlation was supported by a p-value of 0.480087 .

\subsection{Pre-tests Estimation}

\subsubsection{Unit Test}

The root test is used to determine whether or not a time series is predictable. Following prior literature, a number of tests for unit root have been created. However, this study employs the augmented Dickey-Fuller (ADF) and Philip Perron (PP) root unit test. Table 4.3 presents the unit roots results. From Panel B of Table 5 , it is evident that all the series are stationary at level. This situation does not need for cointegration tests, since any short-term shock of the system adapts easily to the long run. It would then be appropriate to forecast only the long-term model. A longrun term model is an astatic model with neither lagged nor differentiated variables using Ordinary Least Square regression.

Table 4. Unit root result

Panel A

\begin{tabular}{|c|c|c|c|c|c|c|}
\hline \multicolumn{7}{|c|}{ LEVEL } \\
\hline & \multicolumn{3}{|c|}{ Augmented- Dickey Fuller (ADF) } & \multicolumn{3}{|c|}{ Philip Perron (PP) } \\
\hline & Constant & $\begin{array}{l}\text { Constant } \\
\text { \& Trend }\end{array}$ & None & Constant & $\begin{array}{l}\text { Constant } \\
\text { \& Trend }\end{array}$ & None \\
\hline TTR & -1.115 & -2.119 & 0.687 & -1.006 & -2.214 & 0.769 \\
\hline CPI & $-3.428 * *$ & 0.972 & 0.706 & -1.937 & -1.062 & 0.992 \\
\hline IE & 0.706 & -1.743 & 2.264 & 2.297 & -1.444 & 4.721 \\
\hline UR & 0.684 & -0.940 & 1.835 & 0.568 & 0.940 & 1.714 \\
\hline \multicolumn{7}{|c|}{ FIRST DIFFERENCE } \\
\hline TTR & $-3.707 * *$ & $-3.615^{*}$ & $-3.478 * * *$ & $-3.879 * * *$ & $-3.934 * *$ & $-3.400 * * *$ \\
\hline CPI & $-6.693 * * *$ & -3.236 & $-5.862 * * *$ & $-6.489 * * *$ & $\begin{array}{l}- \\
16.542 * * *\end{array}$ & $-5.642 * * *$ \\
\hline
\end{tabular}


Johnson, P.N., Omodero, C.O., (2021)

Governance Quality and Tax Revenue Mobilization in Nigeria

\begin{tabular}{|l|l|l|l|l|l|l|}
\hline IE & $04.025^{* * *}$ & $-4.359^{* *}$ & $-3.294^{* * *}$ & $-4.026^{* * *}$ & $-6.344^{* * *}$ & $-3.300^{* * *}$ \\
\hline UR & $-3.463^{* *}$ & $-3.970^{* *}$ & $-3.142^{* * *}$ & $-3.454^{* *}$ & $-4.957^{* *}$ & $-3.118^{* * *}$ \\
\hline
\end{tabular}

Source: Authors Computation with the aid of Eviews 11

Panel B

\begin{tabular}{|l|l|l|l|l|l|l|}
\hline & Augmented- Dickey Fuller (AD) & \multicolumn{4}{l|}{ Philip Perron (PP) } \\
\hline & Level & First Difference & $\mathbf{I}(\boldsymbol{d})$ & Level & $\begin{array}{l}\text { First } \\
\text { Difference }\end{array}$ & I(d) \\
\hline TTR & $-3.066^{b}$ & $-4.312^{\mathrm{a} * * *}$ & $\mathrm{I}(1)$ & $-2.533^{b}$ & $-4.279^{\mathrm{a} * * *}$ & $\mathrm{I}(1)$ \\
\hline CPI & $-5.565^{\mathrm{b} * * *}$ & -- & $\mathrm{I}(0)$ & $-5.648^{\mathrm{b} * * *}$ & -- & $\mathrm{I}(0)$ \\
\hline IE & $\begin{array}{l}- \\
5.268^{\mathrm{a} * * *}\end{array}$ & -- & $\mathrm{I}(0)$ & $-5.268^{\mathrm{a} * * *}$ & -- & $\mathrm{I}(0)$ \\
\hline UR & $-6.395^{\mathrm{a} * * *}$ & -- & & & & \\
\hline
\end{tabular}

Source: Authors Computation with the aid of Eviews 11

Note: 'a' denotes a model with constant, 'b' is for a model with constant and trend and 'c' is the model without constant and trend. Abbreviations.

$* * * \mathrm{p}<0.01$

$* * \mathrm{p}<0.05$

$* \mathrm{p}<0.1$

\subsection{Empirical Findings and Hypotheses Testing}

Table 6 reports the multiple regression results of the effect of governance on tax revenue. The $\mathrm{R}$-squared value identifies the percentage of dependent variability explained by the independent variables in the regression model. From Table 6 , the $\mathrm{R}$-squared basically is 0.908 . Thus, the result reports $90.8 \%$ of the variability in tax revenue is explained by the independent variables. In addition, the Fisher test is significant for both models, indicating a significant linear relationship between the explanatory variables and explained variables.

Table 5. Governance and Tax revenue

Dependent Variable: LOG(TAX REVENUE)

Method: Least Squares

Sample (adjusted): 19962019

Included observations: 21 after adjustments

\begin{tabular}{|l|l|l|l|l|}
\hline \hline Variable & & & & \\
\hline & Coefficient & Std. Error & t-Statistic & Prob. \\
\hline C & & & & \\
\hline CPI & 0.296729 & 0.290889 & 1.020078 & 0.3220 \\
\hline INSECURITY & 1.575153 & 0.329178 & 4.785104 & 0.0002 \\
\hline UNEMP & 0.491387 & 0.142242 & 3.454582 & 0.0030 \\
\hline & -0.022758 & 0.020364 & -1.117544 & 0.2793 \\
\hline
\end{tabular}


Johnson, P.N., Omodero, C.O., (2021)

Governance Quality and Tax Revenue Mobilization in Nigeria

\begin{tabular}{|l|l|l|l|}
\hline R-squared & 0.908225 & Mean dependent var & 3.361615 \\
\hline Adjusted R-squared & 0.892030 & S.D. dependent var & 0.365936 \\
\hline S.E. of regression & 0.120242 & Akaike info criterion & -1.228972 \\
\hline Sum squared resid & 0.245790 & Schwarz criterion & -1.030015 \\
\hline Log-likelihood & 16.90420 & Hannan-Quinn criteria. & -1.185793 \\
\hline F-statistic & 56.07881 & Durbin-Watson stat & 2.364173 \\
\hline Prob(F-statistic) & 0.000000 & & \\
\hline
\end{tabular}

Source: Authors Computation with the aid of Eviews 11

For the purpose of this study the accepted level of significance is $5 \%$. The null hypothesis will be rejected in favor of the alternate if the P-Value (probability value) is less than 0.05 . when the P-value is greater than 0.05 the null hypothesis will be accepted. Therefore, the result of the hypotheses is tested below:

\section{Hypothesis 1}

$\mathrm{H}_{0}$ : There is no significant relationship between corruption and tax revenue in Nigeria.

The results of the regression show the effect of corruption control on tax revenue is positive and significant at a 5\% level of significance. This implies that control of corruption can improve tax revenue. Therefore, the null hypothesis of no significant relationship between corruption and tax revenue in Nigeria is rejected.

\section{Hypothesis 2}

$\mathrm{H}_{0}$ : There is no significant relationship between Political Instability and tax revenue in Nigeria.

The result of the estimation from the regression table showed a positive and statistically significant relationship between political instability and tax revenue at a $5 \%$ level of significance. This suggests that an increase in political instability tends to depreciate the tax revenue mobilization. Therefore, the null hypothesis of no significant relationship between political instability and tax revenue in Nigeria is also rejected.

Hypothesis 3

$\mathrm{H}_{0}$ : The bad governance in Nigeria has no significant effect on tax revenue generation in Nigeria.

From, the regression table the effect of bad governance on tax revenue is positive but insignificant at a 5\% level of significance. Therefore, the null hypothesis of no significant effect of the Nigerian rule of law on tax revenue is accepted.

\subsection{Post Estimation Test}

To assess the validity of underlying presumptions of linear regression models, it is vital to conduct the residual diagnostic tests. Linearity Test (using the Ramsey RESET test), NormalityTest (using the Jarque-Bera test), Serial Correlation Test 
Johnson, P.N., Omodero, C.O., (2021)

Governance Quality and Tax Revenue Mobilization in Nigeria

(using the Breusch-Godfrey LM test), and Heteroscedasticity (using the ARCH LM test) are the most important post-estimation tests for a simple linear regression model.

\subsubsection{The Linearity Test}

From Table 7, regardless of the test statistic used (t-statistic, F-statistic, or likelihood ratio statistic), the null hypothesis of linearity/correct specification cannot be rejected at the 5 percent level of statistical significance.

Table 6. Linearity Test Table

Ramsey RESET Test

Equation: UNTITLED

Specification: LOG(TAX_REVENUE) C CPI INSECURITY UNEMP

Omitted Variables: Squares of fitted values

\begin{tabular}{llll}
\hline \hline & Value & Df & Probability \\
\cline { 2 - 4 } t-statistic & 1.800143 & 16 & 0.1907 \\
F-statistic & 3.240513 & $(1,16)$ & 0.1907 \\
Likelihood ratio & 3.873017 & 1 & 0.1491 \\
\hline \hline
\end{tabular}

F-test summary:

Test SSR

Restricted SSR

\begin{tabular}{ccc} 
Sum of Sq. & Df & Mean Squares \\
\hline 2.277712 & 1
\end{tabular}

Unrestricted SSR

$13.52389 \quad 17$

$\begin{array}{lll}11.24618 & 16 & 0.702886\end{array}$

LR test summary:

Restricted LogL

Value Df

Unrestricted LogL

$\begin{array}{ll}-25.17703 & 17 \\ -23.24052 & 16\end{array}$

Source: Author's Computation with the aid of Eviews 11

\subsubsection{Serial Correlation}

From Table 8, both F-statistic and Obs*R-square fail to reject the null hypothesis of no serial correlation suggesting that there is no presence of serial correlation in the model. Note that the p-values are far higher than any of the conventional levels of statistical significance.

\footnotetext{
30 Journal of Legal Studies Volume 28 Issue 42/2021

$\checkmark$ sciendo ISSN 2457-9017; Online ISSN 2392-7054.

Web: publicatii.uvvg.ro/index.php/jls. Pages $1-41$
} 
Johnson, P.N., Omodero, C.O., (2021)

Governance Quality and Tax Revenue Mobilization in Nigeria

Table 7. Serial Correlation Test Table

Breusch-Godfrey Serial Correlation LM Test:

\begin{tabular}{llll}
\hline \hline F-statistic & 5.520658 & Prob. F(2,15) & 0.1160 \\
Obs*R-squared & 8.903837 & Prob. Chi-Square(2) & 0.1117 \\
\hline
\end{tabular}

Source: Author's Computation with the aid of Eviews 11

\subsubsection{Heteroscedascity Test}

Looking at the p-values of the relevant statistics (F-statistic and Obs*R-square) in

Table 9, we cannot reject the null hypothesis of homoscedasticity.

Table 8. Heteroscedascity Test Table

Heteroskedasticity Test: Breusch-Pagan-Godfrey

\begin{tabular}{llll}
\hline \hline F-statistic & 0.514238 & Prob. F(3,17) & 0.6779 \\
Obs*R-squared & 1.747153 & Prob. Chi-Square(3) & 0.6265 \\
Scaled explained SS & 1.119050 & Prob. Chi-Square(3) & 0.7725 \\
\hline \hline
\end{tabular}

Source: Author's Computation with the aid of Eviews 11

\subsubsection{Normality Test}

The probability value for the Jarque-Berra statistic as shown in the figure below is 0.611 implying that the regression residual is normally distributed irrespective of the chosen level of significance.

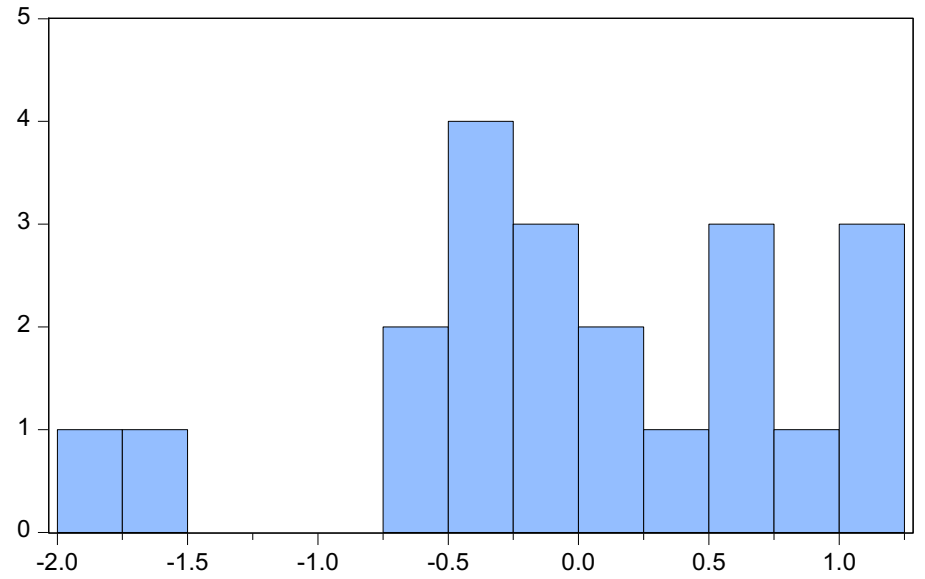

\begin{tabular}{|lr|}
\hline \multicolumn{2}{|l|}{ Series: Residuals } \\
Sample 1996 2019 \\
Observations 21 \\
Mean & $-1.94 \mathrm{e}-15$ \\
Median & -0.017653 \\
Maximum & 1.160369 \\
Minimum & -1.779922 \\
Std. Dev. & 0.822310 \\
Skewness & -0.530441 \\
Kurtosis & 2.954740 \\
& \\
Jarque-Bera & 0.986579 \\
Probability & 0.610614 \\
\hline
\end{tabular}

Figure 1. Normality Test

Source: Author's Computation with the aid of Eviews 11 
Johnson, P.N., Omodero, C.O., (2021)

Governance Quality and Tax Revenue Mobilization in Nigeria

\section{Summary of findings, conclusions, and recommendations}

The goal of this study was to investigate the relationship between governance quality and tax revenue mobilization. The research looked at how corruption, political instability, and bad governance affect Nigeria's mobilization of tax revenue.

\subsection{Theoretical Findings}

According to the benefit received theory and other theories discussed in this literature, corruption, political stability should all have a positive relationship with tax revenue mobilization. However, the findings of this study show that what is obtainable in theory applies to the influence of institutional and political governance on Nigeria's tax revenue. However, bad governance is the least influential on the mobilization of Nigeria's tax revenue.

\subsection{Empirical Findings}

The results of this study revealed a positive correlation between corruption and Nigeria's tax revenue mobilization. According to the conclusions of this study, the control of corruption has a favorable impact on the generation of tax revenue in Nigeria. This study demonstrates that the ability of the government to control corruption and substantially reduce corruption in Nigeria contributes to the improvement of citizens' morale to pay taxes. This means that citizens are encouraged to willingly prevent tax noncompliance, thereby increasing tax revenue generation in Nigeria. On the other hand, this favorable relationship is consistent with the reports of Hossain (2014) and Chariye (2016), which support the idea that corruption control has a favorable relationship with Nigeria's tax revenue.

The research also demonstrated that an increase in government stability (political stability) results in higher tax revenue generation. According to this study, political stability has a favorable and substantial link with Nigeria's tax revenue. As a result, our research suggests that a more legitimate and responsive state is likely a necessary prerequisite for a higher level of tax effort in Nigeria. The positive relationship between political stability and tax revenue mobilization, on the other hand, has added to the existing body of literature and is consistent with the reports of Bird, Martinezvazquez\&Torgler (2007)

Furthermore, this study found that bad governance has a positive and substantial relationship with the country's tax revenue mobilization.

\subsection{Conclusions}

For the period 2000 to 2020 , this study empirically analyzed the relationship between governance quality and tax revenue mobilization in Nigeria. Nigeria's mobilization of tax revenue is reflected in a rise in the total tax revenue.

$$
\begin{aligned}
& 32 \\
& S \text { sciendo }
\end{aligned} \begin{aligned}
& \text { Journal of Legal Studies Volume 28 Issue 42/2021 } \\
& \text { ISSN 2457-9017; Online ISSN 2392-7054. } \\
& \text { Web: publicatii.uvvg.ro/index.php/jls. Pages } 1-41
\end{aligned}
$$


Johnson, P.N., Omodero, C.O., (2021)

Governance Quality and Tax Revenue Mobilization in Nigeria

The correlation results show that there is a substantial relationship between corruption, political instability and the dependent variable, tax revenue. Bad governance, moreover, was found to have a moderate link with tax revenue. Furthermore, the results reveal that the empirical model was statistically significant for all independent variables, indicating that it may be trusted. As a result, the null hypotheses for corruption and political instability are rejected, while that of bad governance is accepted. As a result, the following is shown:

a. $\mathrm{H}_{1}(1)$ : Corruption has a significant effect on tax revenue mobilization in Nigeria.

b. $H_{1}(2)$ : Political instability has a significant effect on tax revenue mobilization in Nigeria.

c. $\mathrm{H}_{0}(3)$ : Bad governance has no significant effect on tax revenue mobilization in Nigeria.

\subsection{Recommendations}

The following suggestions are made based on the findings of this study:

1) The taxpayers' view of the government determines the validity of the social contract between them and the government. Citizens and businesses will be more eager to be tax compliant if they have a favourable opinion of the government's utilization of tax receipts. All states and the federal government should enact policies requiring the periodic publication of pertinent information on tax collection and taxpayer profiling. Finland publishes all citizens' taxable income, including the tax data of celebrities and politicians, as part of the government's tax transparency initiative. According to the results of a poll performed by the country's tax administrator in 2017, this step has helped to broaden the country's tax base. To increase tax morale and broaden the tax base, Nigeria should adopt a strategy similar to this.

2) A direct link between tax payment and the use of government-provided facilities and services may raise tax awareness and, as a result, tax compliance rates. Lagos State has sought to do so by stamping "pay your tax" on nearly all of its infrastructure and public-service documents. As a result, Lagos citizens are well aware of the connection between tax payment and the continued availability of and access to public services. This strategy appears to be succeeding since Lagos State alone collected more than 30\% of all taxes collected by state governments and the FCT in 2018.

3) In addition to raising public awareness, documentation of tax compliance should be a requirement for receiving certain benefits. Companies or businesses that do not have proof of tax registration, for example, should not be able to use the Central Bank of Nigeria's intervention facilities. In this 
Johnson, P.N., Omodero, C.O., (2021)

Governance Quality and Tax Revenue Mobilization in Nigeria

regard, the clause of the Finance Act of 2019 that makes mandatory tax registration a requirement before opening a bank account is particularly laudable. Governments at all levels must ensure that this program is fully implemented and support more initiatives that limit access to certain public benefits for delinquent taxpayers and tax evaders.

4) To stimulate willingness, the government, on the other side, must prioritize the provision of services in its tax compliance efforts. Sweden has one of the highest tax rates in the world, with taxes accounting for $48.2 \%$ of GDP on average. In Sweden, high-income individuals may have to pay as much as 49-60 percent of their earnings in personal income tax. According to a study, Swedes are pleased to pay taxes since their children receive free education up to university level, free meals in schools, free health and dental care for under-18s, and a child stipend of $\$ 1,500$ per child per year.

5) The government should also endeavor to improve the efficiency of its civil forces, which are in charge of detecting and preventing crime in society. States must urgently implement policy reforms that will make their judicial systems and civil forces more autonomous and efficient. Investors become passive as a result of an unstable political environment, as well as an inefficient legal and civil force system, and they avoid long-term investments. As a result, the economy's growth and overall tax revenue are slowed. When democratic and political institutions begin to function effectively, taxpayers will be able to freely express their complaints about the tax system, tax administrations will become more transparent and publicly responsible, and emerging nations' tax collections will improve.

6) Government must devise a strategy that may involve offering monetary incentives to fiscal officers, so lowering the incentive for them to commit corruption. Furthermore, rather than raising tax rates, tax administrators should focus on extending the tax base to increase tax collections. Politicians and the wealthy benefit from higher tax rates because they have more opportunities to avoid paying taxes. As a result, high tax rates provide more opportunities for corruption.

\subsection{Contribution to Knowledge}

This study contributes to Nigeria's growing belief in good governance and tax revenue collection. To begin with, this study adds to the limited academic studies on the quality of governance and its impact on Nigeria's income development. Unlike previous studies, this one uses only variables that represent institutional and political governance, and it is hoped that the government will find it useful in determining the impact of their organizational inequalities on tax revenue generation, thus hastening improvements in the quality of their service to the people. 
Johnson, P.N., Omodero, C.O., (2021)

Governance Quality and Tax Revenue Mobilization in Nigeria

By examining governance quality and tax revenue mobilization in Nigeria, this study adds to current understanding. However, a review of the literature found that no study has looked at the impact of both institutional and political governance on tax income in Nigeria. As a result, it was considered for inclusion in this research.

\subsection{Limitation to Study}

This study looked at the impact of governance quality and tax revenue generation in Nigeria during a 20-year period, from 2000 to 2020. Moreso, although just three proxies were used to measure governance quality in this study, some other relevant proxies may be considered useful.

\subsection{Suggestion for Further Studies}

A follow-up study should be undertaken to supplement the findings of this one, according to this study. Instead of focusing on Nigeria, it suggests that further studies be performed in other countries. Scholars may add moderator factors into new research models in the future. Future research may take into account other factors that influence Nigeria's tax revenue mobilization, such as rule of law, regulation quality, and government effectiveness.

\section{Acknowledgments}

I hereby acknowledge that this research was conducted as part of my BSc project research for the award of a BSc Degree in Accounting from Covenant University Nigeria. My thanks go to my supervisor, Dr. Cordelia Omodero, for her firmness, timely, decisive, and invaluable advice, as well as positive criticisms that were challenging but enabled me to strive to achieve the study's goal. I would like to express my gratitude to the administration of Covenant University Ota in Ogun State, Nigeria, for providing me with the opportunity to conduct this research.

\section{Funding}

This research received no specific grant from any funding agency in the public, commercial, or not - for - profit sectors.

\section{Author Contributions}

Peace Ngozi Johnson and Dr. Cordelia Onyinyechi Omodero conceptualized the study and were in charge of its design and data processing. Peace Ngozi Johnson and Dr. Cordelia Onyinyechi Omodero were in charge of data collection, processing, and interpretation. Peace Ngozi Johnson was in charge of the literature review, conclusion, and suggestion. Dr. Cordelia Onyinyechi Omodero was in charge of research supervision and general correction. 
Johnson, P.N., Omodero, C.O., (2021)

Governance Quality and Tax Revenue Mobilization in Nigeria

\section{Disclosure Statement}

The authors have not any competing financial, professional, or personal interests from other parties.

\section{References}

1. Abed, T. G., Gupta S., (2002). Governance, Corruption and Economic Performance. IMF Working Paper.

2. Adedokun, A. A., (2007). Local Government tax Mobilization and Utilization in Nigeria: Problems and Prospects. Ibadan: Book Presentation.

3. Agya, A. A., Ibrahim, Y. M., Emmanuel, E. (2015). Internal revenue generation in Taraba State, Nigerial: Problems and prospects. International Journal of Economics, Commerce and Management. 3(2).1-13.

4. Ajaz, T., Ahmad, E., (2010). The effect of corruption and governance on tax revenues. The Pakistan Development Review, 49(4), 405 - 417.

5. Akintoye, I. R., Adegbie, F. F., Awotomilusi, N. S., (2019). Influence of voice and accountability on tax revenue in Nigeria. International Journal of Research and Innovation in Social Science, 3(4), 81-89.

6. Akpo, U., (2009). The people as government: The importance of tax payment. Akwa Ibom State Revenue Summit. Akwa Ibom State Internal Revenue Service.

7. Alabede, J. O., (2001). Improving the efficiency of tax administration for effective revenue generation in democratic Nigeria. In SBS national conference.

8. Alabede, J. O., Affrin, Z. Z., (2011). Public governance quality and tax compliance behavior in Nigeria: The moderating role of financial condition and risk preference. Issues in Social and Environmental Accounting (ISEA), 5(1/2), 3-24.

9. Alabede, J. O., Affrin, Z. Z., (2011). Tax service quality and compliance behavior in Nigeria: Do taxpayer's financial condition and risk preference play any moderating role? European Journal of Economics, Finance and Administrative Sciences, (35), 90-108.

10. Alabede, J. O., Ariffin, Z. Z., Idris, K. M., (2011). Determinants of tax compliance behavior: A proposed model for Nigeria. International Research Journal of Finance and Economics, 78(1), 121-136.

11. Alm, J., Gomez, J. L., (2008). Social capital and tax morale in Spain. Economic Analysis and Policy, 38(1), 73-87.

12. Alm, J., Martinez-Vazquez, J., (2003). Institutions, paradigms, and tax evasion in developing and transition countries. In Public finance in developing and transitional contries: essays in honor of Richard Bird. Edward Elgar Publishers, 146-178.

13. Alm, J., \& Torgler, B. (2011). Do ethics matter? Tax compliance and morality. Journal of Business Ethics, 101(4), 635-651.

14. Alm, J., Jackson, B. R., McKee, M., (1992). Estimating the determinants of taxpayer compliance with experimental data. National Tax Journal, 45(1), 107-114.

15. Alm, J., Martinez-Vazquez, J., Schneider, F., (2004). 'Sizing'the Problem of the Hard-toTax. Contributions to Economic Analysis, 268, 11-75.

16. Alm, J., McClelland, G. H., Schulze, W. D., (1992). Why do people pay taxes?. Journal of Public Economics, 48(1), 21-38. 
Johnson, P.N., Omodero, C.O., (2021)

Governance Quality and Tax Revenue Mobilization in Nigeria

17. Anao, R. A., (1988). The Structure of the Nigerian Tax System in Nigeria, Ibadan: Nigerian Institute of Social and Economic Research.

18. Arif, I., \& Rawat S. A. (2018). Corruption, governance, and tax revenue: evidence from EAGLE countries. Journal of transnational Management, vol. 23, no. 2-3, pp. 119-133, 2018.

19. Ariyo, A., Bekoe, W., (2012). Currency demand, the underground economy and tax evasion: The case of Nigeria. Journal of Monetary and Economic Integration, 11(2), 129157.

20. Atakpa, M., Ocheni, S., Nwankwo, B. C., (2012). Analysis of options for Maximizing Local Government internally generated Revenue in Nigeria. International journal of learning and Development, 2(5), 94-104.

21. Attila, J., (2008). Corruption, taxation and economic growth: theory and evidence. CERDI, Etudes et Documents, 29, 1-27.

22. Bahl, R., Smoke, P., Solomon, D., (2003). Overview of the local government revenue system. In (eds.) Restructuring Local Government Finance in developing Countries: Lessons from South Africa, Edward Elgar Publishing, Chapter, 3, 71-93.

23. Besançon, M., (2003). Good governance rankings. The art of Measurement. World Peace Foundation. WPF Reports, 36.

24. Bird, R. M., (2004). Land taxes in Colombia. Chapters.

25. Bird, R. M., Martinez-Vazquez, J., Torgler, B., (2008). Tax effort in developing countries and high-income countries: The impact of corruption, voice and accountability. Economic analysis and policy, 38(1), 55-71.

26. Bird, R. M., Martinez-Vazquez, J., Torgler, B., (2014). Societal institutions and tax effort in developing countries. Annals of Economics and Finance, 15(1), 185-230.

27. Bitzenis, A., Vlachos, V., (2018). Tax morale in times of economic depression: The case of Greece. Advances in Taxation, 25, 173-199.

28. Chariye, A. B., (2016). The impact of corruption on tax morale: A study of select business organizations in Addis Ababa, Ethiopia. International Journal of Economics and Finance Studies, 8(1), 48-60.

29. Cobham, A., (2005). Tax evasion, tax avoidance and development finance. Queen Elizabeth House, Série documents de travail, 129, 1-20.

30. Deng, H., (2015). Improving the Legal Implementation Mechanisms for A Carbon Tax in China. Pace Environmental Law Review, 32(3), 2.

31. Dibie, R., Dibie, R., (2020). Analysis of the determinants of tax policy compliance in Nigeria. Journal of Public Administration and Governance, 10(2).

32. Dickerson, C. M., (2014). Bringing formal business laws to Cameroon's informal sector: lessons and cautions from the tax law example. Wash. U. Global Stud. L. Rev., 13, 265.

33. Dickinson, B., (2010). Tax and Good Governance. OECD Journal: General Papers.

34. Dickson, E., Presley. E., (2013). Tax incentives and revenue productivity of the Nigerian tax system. International Journal of Development and Economic Sustainability, 1(1), 33-44.

35. Djayasinga, M., Prasetyo, T. J., (2019). The effect of government effectiveness, rule of law and control of corruption toward tax obedience. Religación, 4, 136-143.

36. Djumashev, R., (2007). Corruption, uncertainty and growth. MPRA Paper No. 3716, 139. 
Johnson, P.N., Omodero, C.O., (2021)

Governance Quality and Tax Revenue Mobilization in Nigeria

37. Drummond, M. P., Daal, M. W., Srivastava, M. N., Oliveira, M. L. E., (2012). Mobilizing revenue in Sub-Saharan Africa: empirical norms and key determinants. IMF Working Paper, $1-43$.

38. Ebrill, M. L. P., Keen, M. M., Perry, M. V. P., (2001). The modern VAT. International Monetary Fund.

39. Epaphra, M., Massawe, J., (2017). Corruption, governance and tax revenues in Africa. Business and Economic Horizons, 13(4), 439-467.

40. Eshag, E., (1983). Fiscal and monetary policies and problems in developing countries. Cambridge University Press.

41. Everest-Phillip, M., Sandall, R., (2009). Linking business tax reform with governance: How to measure success. Working paper, Investment Climate Department, World Bank Group.

42. Fagbadebo, O., (2007). Corruption, governance and political instability in Nigeria. African Journal of Political Science and International Relations, 1(2), 028-037.

43. Federal Government of Nigeria., (2019). CBN Statistical Bulletin.

44. Feige, E. L., (1989). The meaning and measurement of the underground economy. Feige, EL (1989a), 13-56.

45. FIRS., (2020). Finance Act 2019.

46. Fjeldstad, O. H., (2005). Revenue administration and corruption. U4 Issue.

47. Fjeldstad, O. H., (2005). Corruption in tax administration: Lessons from institutional reforms in Uganda. Chr. Michelsen Institute.

48. Fjeldstad, O. H., Schulz-Herzenberg, C., Hoem Sjursen, I., (2012). People's views of taxation in Africa: a review of research on determinants of tax compliance. Available at SSRN 2411424.

49. Franzoni, L. A., (2000). Amnesties, settlements and optimal tax enforcement. Economica, 67(266), 153-176.

50. Friedman, M., (1978). The limitations of tax limitation. Quadrant, 22(8), 22-24.

51. Ghura, D., (1998). Tax Revenue in Sub-Saharan Africa: Effects of Economic Policies and Corruption. Working paper of the International Monetary Fund, 1-25.

52. Gupta, A. S., (2007). Determinants of Tax Revenue Efforts in Developing Countries. IMF Working Paper, 1-39.

53. Hassan, I., Naeem, A., Gulzar, S., (2021). Voluntary tax compliance behavior of individual taxpayers in Pakistan. Financial Innovation, 7(1), 1-23.

54. Hossain, S., (2014). Disclosure in Financial Statement on the basis of BASs: A Study on Listed Pharmaceutical Companies in Bangladesh. Independent Business Review, 7(1), 8396.

55. Imam, P. A., Jacobs, D., (2007). Effect of corruption on tax revenues in the Middle East. IMF Working Paper. WP/07/ 270.

56. Jain, A. K., (2001). Corruption: A review. Journal of economic surveys, 15(1), 71-121.

57. Jimoh, B. A., Adegoriola, A. E., Adeyemo, T., (2019). Empirical analysis of the impact of tax revenue on economic growth in Nigeria. Bigham Journal of Economics and Allied Studies, 3(1), 100-110.

58. Joulfaian, D., (2009). Bribes and business tax evasion. European Journal of Comparative Economics, 6(2), 227-244.

38 Journal of Legal Studies Volume 28 Issue 42/2021

$\checkmark$ sciendo ISSN 2457-9017; Online ISSN 2392-7054.

Web: publicatii.uvvg.ro/index.php/jls. Pages $1-41$ 
Johnson, P.N., Omodero, C.O., (2021)

Governance Quality and Tax Revenue Mobilization in Nigeria

59. Joyce, N., (2014). Determinants of revenue collection in developing countries: Kenya's

Tax Collection. Journal of Management and Business Administration 1(1):1-2.

60. Kebede, M., Tegegn, T., (2016). Problems Associated with Taxpayers and Revenue Authority in Case of Dessie Town, Northern Ethiopia. Journal of Poverty, Investment and Development, 25, 56-64.

61. Kim, J. T., (2002). A Study on Taxation Electronic Commerce. Korean Business Review, $15,59-78$.

62. Kirchler, E., (2007). The economic psychology of tax behavior. Cambridge University Press.

63. Lassen, D. D., (2003). Ethnic division and the size of the informal sector. Working paper, Institute of Economics, University of Copenhagen.

64. Levi, M., (1988). Of rule and revenue. Berkeley: University of California.

65. Litina, A., Palivos, T., (2016). Corruption, tax evasion and social values. Journal of Economic Behavior \& Organization, 124, 164-177.

66. Madueke, C. N. Z., (2008). The role of leadership in governance: The Nigerian Experience. Doctoral dissertation, Walden University.

67. Mallick, H., (2020). Do governance quality and ICT infrastructure influence tax revenue mobilization? An empirical analysis for India. https://doi.org/10.1007/s10644-020-09282-9.

68. Mauro, P., Medas, P. A., Fournier, J. M., (2019). The Cost of Corruption: Graft results in lost tax revenue, but it also takes a social toll. Finance \& Development, 56(003).

69. McGee, R. W., (2006). Three views on the ethics of tax evasion. Journal of Business Ethics, 67(1), 15-35.

70. Meagher, K., (2018). Taxing times: Taxation, divided societies and the informal economy in Northern Nigeria. The Journal of development studies, 54(1), 1-17.

71. Mukhlis, I., Utomo, S. H., Soesetyo, Y., (2014). Increasing tax compliance through strengthening the capacity of the education sector for export-oriented SMEs handicraft field in East Java Indonesia. European Scientific Journal, 10(7).

72. Naiyeju, J. K., (1996). Improving the Nigerian tax system from the Canadian experience. Wordsmith Printing and Packaging ltd, 101-104.

73. Natufe, O. I., (2006). Governance and politics in Nigeria. In A lecture delivered at Staff and Graduate Seminar, Department of Politics and Public Administration, University of Benin.

74. Ngerebo, T. A., Masa, A., (2012). Appraisal of the tax system in Nigeria (a case study of value-added tax). Research Journal in Organizational Psychology and Educational Studies, $1(6), 338-344$.

75. Ochiogu. A.C., (2014) Nigeria Taxation for Students, Enugu. A.C Ochiogu Publishers.

76. Ogbuabor, J. E., Aneke, G. C., Ogbuabor, C. A., (2014). Informal Sector and Domestic Resource Mobilization in Nigeria: A Community Taxation Option. European Journal of Social Sciences, 43(4), 360-370.

77. Ojo, S., (2008). Fundamental Principles of Nigerian Tax, Lagos.

78. Okon, E., (2007). Poverty alleviation and the control of public revenue in Nigeria: legal and equitable issues. The Pretoria Student Law Review, 1.

79. Oriakhi, D. E., Ahuru, R. R., (2014). The impact of tax reform on federal revenue generation in Nigeria. Journal of Policy and Development Studies, 9(1), 92-108. 
Johnson, P.N., Omodero, C.O., (2021)

Governance Quality and Tax Revenue Mobilization in Nigeria

80. Owens, J., (2015). Promoting Good Tax-Governance in Third-Countries: The Role of The EU. European Parliament Directorate-General for Internal Policies, 1-19.

81. Regoniel, P. A., (2015). Conceptual framework: A step-by-step guide on how to make one. SimplyEducate. Me.

82. Rodriguez, P., Uhlenbruck, K., Eden, L., (2005). Government corruption and the entry strategies of multinationals. Academy of management review, 30(2), 383-396.

83. Rose-Ackerman, S., (1997). The political economy of corruption. Corruption and the global economy, 31(60), 54.

84. Ross, M., (2004). Does Taxation Lead to Representation? B.J.Pol.S., Cambridge University Press, 230.

85. Saibu, M., Olasunbo S., (2013). Macroeconomic determinants of tax revenue in Nigeria (1970-2011). World applied sciences 27.

86. Schlenther, B., (2017). The impact of corruption on tax revenues, tax compliance and economic development: Prevailing trends and mitigation actions in Africa. eJTR, 15, 217.

87. Sebele-Mpofu, F. Y., (2020). Governance quality and tax morale and noncompliance in Zimbabwe's informal sector, Cogent Business \& Management, vol. 7, no. 1, Article ID 1794662.

88. Syadullah, M., (2015). Governance and tax revenue in Asian countries. Journal of Social and Development Sciences, 6(2), 76-88.

89. Tanzi, V., Davoodi, H., (1998). Corruption, public investment, and growth. In The welfare state, public investment, and growth, Springer, Tokyo, 41-60.

90. Terefe, K. D., Teera, J., (2018). Determinants of tax revenue in East African countries: An application of multivariate panel data cointegration analysis. Journal of Economics and International Finance, 10(11), 134-155.

91. Terkper, S., (2003). Managing small and medium-size taxpayers in developing economies. Tax notes international, 29(2), 211-229.

92. Topal, M. H., Sahin, M., (2017). Governance quality and taxation: A panel co-integration evidence for OECD countries. Studies on Balkan and Near Eastern Social Sciences, Peter Lang Academic Research.

93. Torgler, B., (2003). Tax morale: Theory and empirical analysis of tax compliance. Doctoral dissertation, University of Basel.

94. Torgler, B., (2004). Tax morale, trust and corruption: Empirical evidence from transition countries (No. 2004-05). CREMA Working Paper.

95. Torgler, B., (2005). Tax morale and direct democracy. European Journal of Political economy, 21(2), 525-531.

96. Torgler, B., Schneider, F. (2009). The impact of tax morale and institutional quality on the shadow economy. Journal Of Economic Psychology, 30(2), 228-245.

97. Torgler, B., Schaltegger, C. A., (2006). Tax morale: A survey with a special focus on Switzerland. Swiss Journal of Economics and Statistics (SJES), 142(III), 395-425.

98. Torgler, B., Schaffner, M., Macintyre, A., (2007). Tax compliance, tax compliance, tax morale, and governance quality. International Studies Program Working Paper, 727.

99. Torgler, B., Schaffner, M., Macintyre, A., (2007). Tax compliance, tax morale and governance quality (No. 2007-17). CREMA Working Paper.

\footnotetext{
40 Journal of Legal Studies Volume 28 Issue 42/2021

$\checkmark$ sciendo ISSN 2457-9017; Online ISSN 2392-7054.

Web: publicatii.uvvg.ro/index.php/jls. Pages $1-41$
} 
Johnson, P.N., Omodero, C.O., (2021)

Governance Quality and Tax Revenue Mobilization in Nigeria

100. Umar, M. A., Derashid, C., Ibrahim, I., Bidin, Z., (2019). Public governance quality and tax compliance behavior in developing countries: the mediating role of socioeconomic conditions. International Journal of Social Economics.

101. Urhoghide, R. O., Asemota, G. O., (2013). Determinants Of Tax Revenue Effort: Empirical Evidence from Nigeria. Leadership \& Organizational Management Journal, 2013(2).

102. Vlachos, V., Bitzenis, A., (2018). Corruption and tax compliance of greek SMEs. In Economy, finance and business in Southeastern and Central Europe, Springer, Cham, 413418.

103. Wenzel, M., (2003). Tax compliance and the psychology of justice: Mapping the Weld. In V. Braithwaite (Ed.), Taxing Democracy: Understanding Tax Avoidance and Evasion, Hants, UK: Ashgate, 41-69.

104. Zulal S., (2005). Endogenous growth, taxes and government spending: Theory and Evidence. Review of Development Economics, Willey Blackwell, 11(1), 124-138. 